Taking the Challenge at Singer Village-A Cold Climate Zero Energy Ready Home

S. Puttagunta and O. Faakye

Consortium for Advanced Residential Buildings 


\section{NOTICE}

This report was prepared as an account of work sponsored by an agency of the United States government. Neither the United States government nor any agency thereof, nor any of their employees, subcontractors, or affiliated partners makes any warranty, express or implied, or assumes any legal liability or responsibility for the accuracy, completeness, or usefulness of any information, apparatus, product, or process disclosed, or represents that its use would not infringe privately owned rights. Reference herein to any specific commercial product, process, or service by trade name, trademark, manufacturer, or otherwise does not necessarily constitute or imply its endorsement, recommendation, or favoring by the United States government or any agency thereof. The views and opinions of authors expressed herein do not necessarily state or reflect those of the United States government or any agency thereof.

Available electronically at http://www.osti.govscitech

Available for a processing fee to U.S. Department of Energy and its contractors, in paper, from:

U.S. Department of Energy

Office of Scientific and Technical Information

P.O. Box 62

Oak Ridge, TN 37831-0062

phone: 865.576 .8401

fax: 865.576.5728

email: mailto:reports@adonis.osti.gov

Available for sale to the public, in paper, from:

U.S. Department of Commerce

National Technical Information Service

5285 Port Royal Road

Springfield, VA 22161

phone: 800.553 .6847

fax: 703.605.6900

email: orders@ntis.fedworld.gov

online ordering: http://www.ntis.gov/ordering.htm 


\title{
Taking the Challenge at Singer Village- A Cold Climate Zero Energy Ready Home
}

\author{
Prepared for:
}

The National Renewable Energy Laboratory

On behalf of the U.S. Department of Energy's Building America Program

Office of Energy Efficiency and Renewable Energy

15013 Denver West Parkway

Golden, CO 80401

NREL Contract No. DE-AC36-08GO28308

\author{
Prepared by: \\ Srikanth Puttagunta and Omari Faakye \\ Steven Winter Associates, Inc. \\ Consortium for Advanced Residential Buildings \\ 61 Washington Street \\ Norwalk, CT 06854 \\ NREL Technical Monitor: Stacey Rothgeb \\ Prepared under Subcontract No. KNDJ-0-40342-04
}

October 2014 
The work presented in this report does not represent performance of any product relative to regulated minimum efficiency requirements.

The laboratory and/or field sites used for this work are not certified rating test facilities. The conditions and methods under which products were characterized for this work differ from standard rating conditions, as described.

Because the methods and conditions differ, the reported results are not comparable to rated product performance and should only be used to estimate performance under the measured conditions. 


\section{Contents}

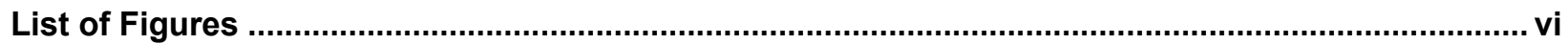

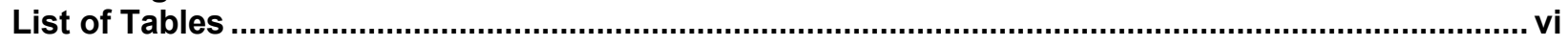

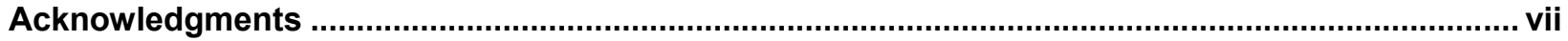

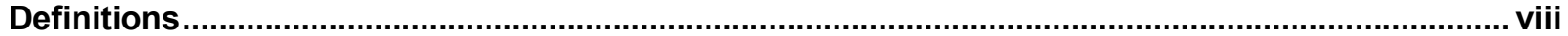

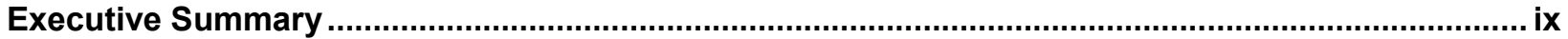

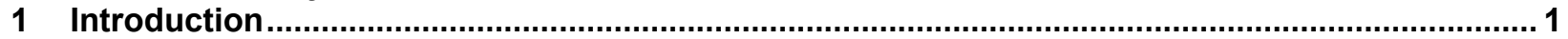

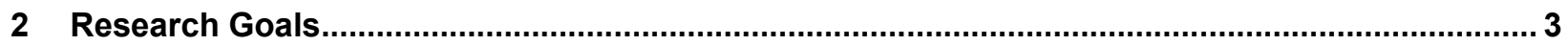

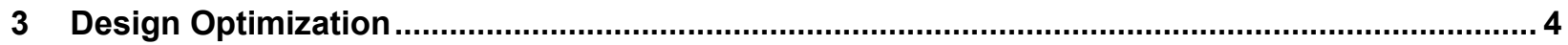

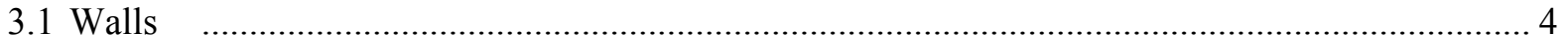

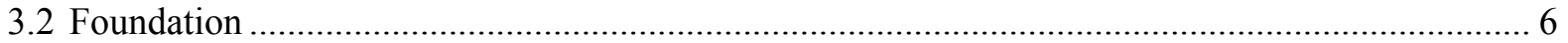

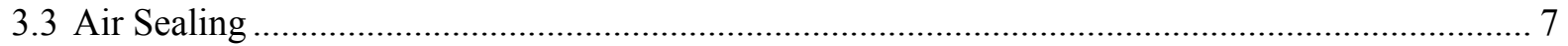

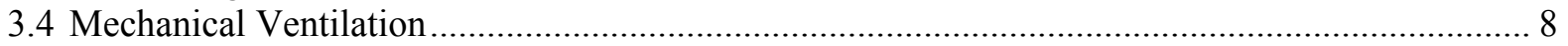

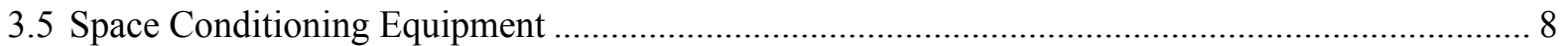

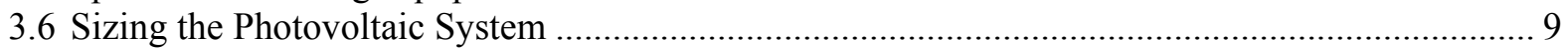

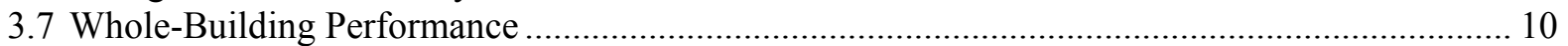

4 Implementation of a U.S. Department of Energy Zero Energy Ready Home............................... 18

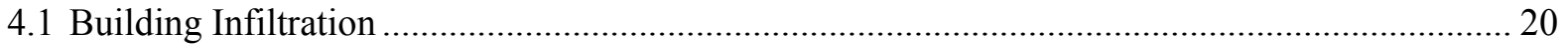

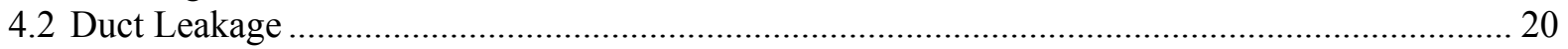

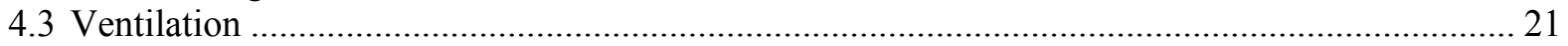

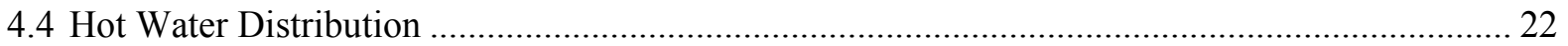

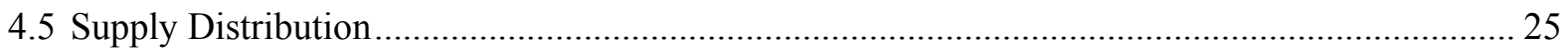

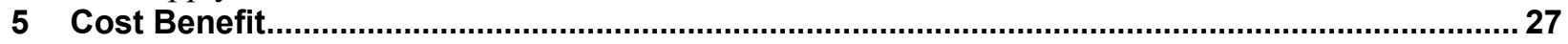

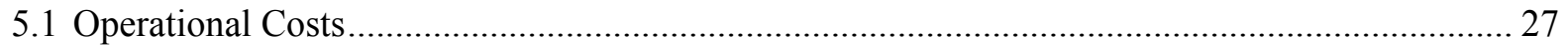

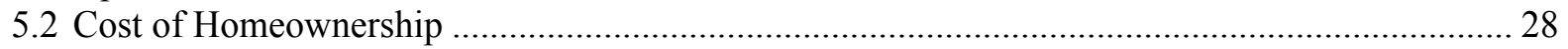

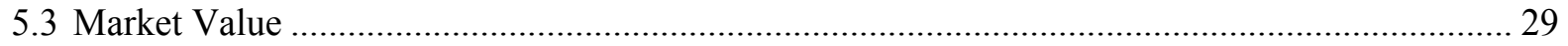

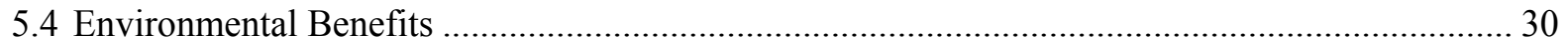

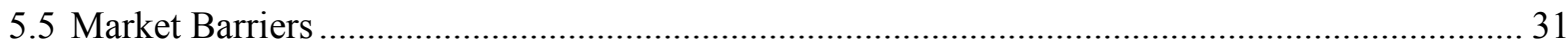

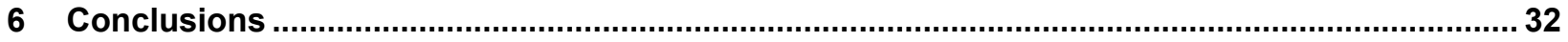

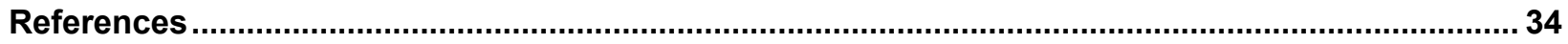

Appendix A: Impact of Mortgage Interest Rate on Cost Analysis .............................................. 35

Appendix B: Impact of Fuel Escalation Rate on Cost Analysis ................................................... 36 


\section{List of Figures}

Figure 1. Previous Brookside Development home in Derby, Connecticut ...................................... 1 Figure 2. Estimated average monthly homeownership costs from Builder's marketing literature.... 2

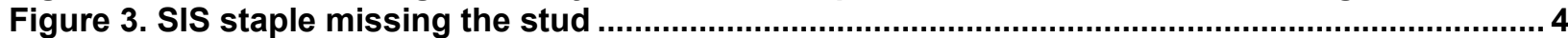

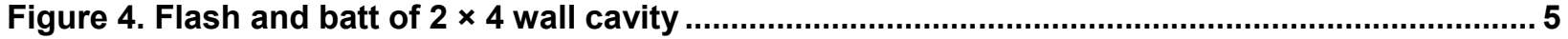

Figure 5. Different wall insulations considered by the builder ...................................................... 6

Figure 6. Air sealing critical transition between sill plate and foundation wall.................................. 6

Figure 7. Analysis of infiltration impact on building performance .................................................. 7

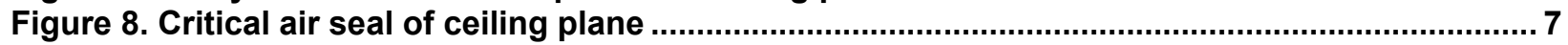

Figure 9. Performance comparison of mechanical ventilations systems ............................................ 8

Figure 10. Utility cost analysis for various heat pump cutoff temperatures ....................................... 9

Figure 11. Estimating appropriate PV system size to offer to homeowners ................................... 10

Figure 12. BEopt optimization analysis with proposed design and as-built home ........................ 12

Figure 13. The first home in the Singer Estate Development..................................................... 13

Figure 14. Condensing tankless water heater........................................................................... 14

Figure 15. Cumulative contribution to total energy savings by measure and end use .....................16

Figure 16. Several critical building envelope details .......................................................................... 19

Figure 17. Air sealing around the air handler compartment..................................................... 21

Figure 18. Estimated DHW volume stored in distribution piping................................................ 22

Figure 19. On-demand recirculation pump installed at furthest fixture ........................................... 23

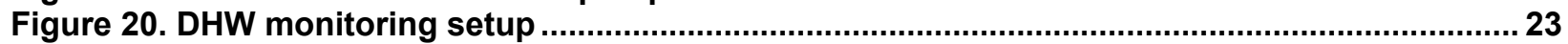

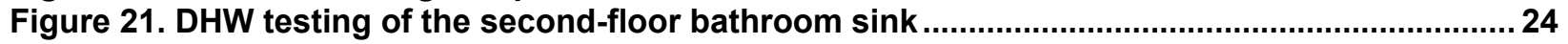

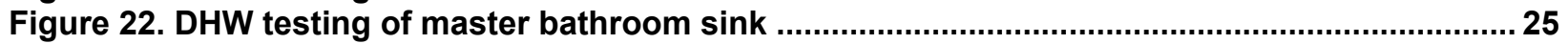

Figure 23. Measuring airflows with a low flow balometer............................................................. 25

Figure 24. Comparison of design versus measured airflow before and after balancing (redline

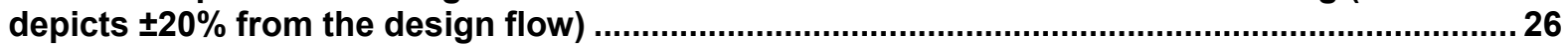

Figure 25. Cumulative contribution to utility bills by measure and end use ................................... 27

Figure 26. Utility costs savings of the Singer Village demonstration home over alternative

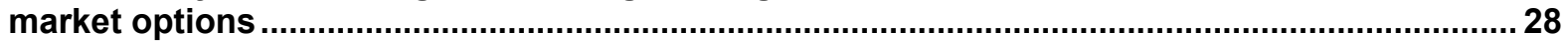

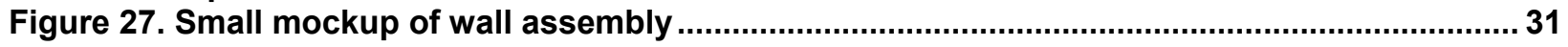

Unless otherwise noted, all figures were created by CARB.

\section{List of Tables}

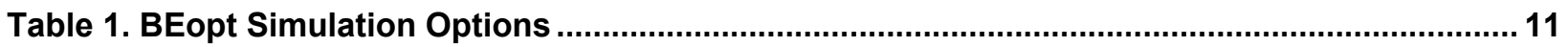

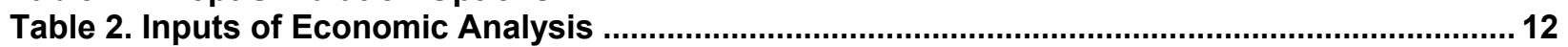

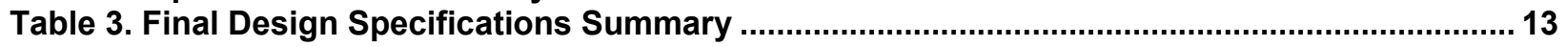

Table 4. Final Design Solution Package Comparison to BEopt Least-Cost Package.........................14

Table 5. Defining User Profiles in Energy Model ............................................................................... 17

Table 6. Utility Cost and Percentage Energy Savings for the Three User Profiles ..........................17

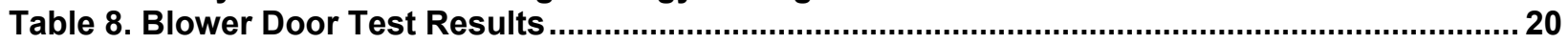

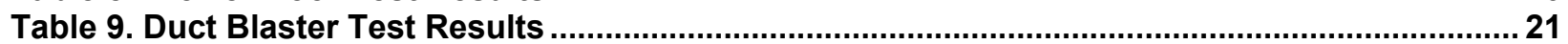

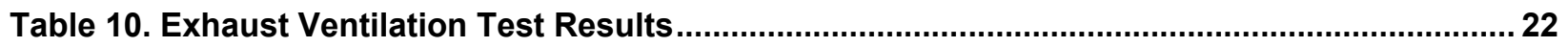

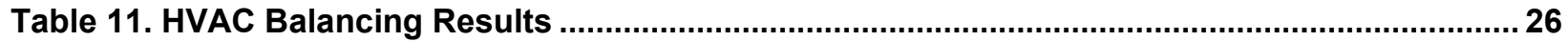

Table 12. Homeownership Cost Comparison of Brookside Development's Zero Energy Ready

Home Versus Similar Lower Performance Homes.................................................................. 29

Table 13. Estimated Builder Return on Investment for Various Energy Efficiency Measures.......... 30

Table 14. Reduction in Greenhouse Gas Emissions ....................................................................... 31

Unless otherwise noted, all tables were created by CARB. 


\section{Acknowledgments}

Steven Winter Associates, Inc. acknowledges the U.S. Department of Energy Building America program and its funding and support for the development of this technical report as well as research that informed it. Steven Winter Associates would like to thank Mark Nuzzolo and DJ Collins of Brookside Development for partnering on this demonstration home. It is a pleasure to work with a builder who has a greater vision of what the construction business is about and the willingness to push the market in that direction. Steven Winter Associates would also like to thank Jennifer Parsons of the United Illuminating Company and Enoch Lenge of Northeast Utilities Service Company for their partnership and support through Energize Connecticut and the Connecticut Zero Energy Challenge. 


\section{Definitions}

$\mathrm{ACH}_{50}$

$\mathrm{ACH}_{\text {nat }}$

AERC

AFUE

ASHP

BA

BEopt

CARB

ccSPF

CFM

$\mathrm{CFM}_{25}$

$\mathrm{CFM}_{50}$

DOE

DHW

EF

ERV

${ }^{\circ} \mathrm{F}$

FGB

HERS

HSPF

HVAC

IECC

$\mathrm{kW}$

o.c.

ocSPF

OSB

PV

ROI

SEER

SHGC

SIS
Air Changes Per Hour at 50 Pascal Depressurization

Natural Air Changes Per Hour

Annualized Energy-Related Cost

Annual Fuel Utilization Efficiency

Air-Source Heat Pump

Building America Program

Building Energy Optimization Software

Consortium for Advanced Residential Buildings

Closed-Cell Spray Polyurethane Foam

Cubic Feet Per Minute

Cubic Feet Per Minute at 25 Pascal Depressurization

Cubic Feet Per Minute at 50 Pascal Depressurization

U.S. Department of Energy

Domestic Hot Water

Energy Factor

Energy Recovery Ventilator

Degree Fahrenheit

Fiberglass Batt

Home Energy Rating System

Heating Season Performance Factor

Heating, Ventilation, and Air Conditioning

International Energy Conservation Code

Kilowatt

On Center

Open-Cell Spray Polyurethane Foam

Oriented Strand Board

Photovoltaic

Return on Investment

Seasonal Energy Efficiency Ratio

Solar Heat Gain Coefficient

Structurally Insulated Sheathing 


\section{Executive Summary}

In addition to advanced building science research, the U.S. Department of Energy's (DOE) Building America (BA) program also works with builder partners to vet production-friendly building solution packages in specific climate zones that are exceptionally energy efficient, address indoor air quality, and deliver a comfortable living environment. For this demonstration home, the Consortium for Advanced Residential Buildings (CARB), a BA research team, partnered with Brookside Development on the design optimization and construction of the first home in a small development of seven planned new homes being built on the old Singer Estate in Derby, Connecticut. After incorporating ENERGY STAR ${ }^{\circledR}$ for Homes Version 1, 2, and 3 into its builder standard practices, Brookside Development was seeking to build an even more sustainable product that would further increase energy efficiency, while also addressing indoor air quality, water conservation, renewable-ready, and resiliency. These objectives align with the framework of the DOE Zero Energy Ready Home program (previously referred to as the DOE Challenge Home program), which "builds upon the comprehensive building science requirements of ENERGY STAR for Homes Version 3, along with proven Building America innovations and best practices. Other special attribute programs are incorporated to help builders reach unparalleled levels of performance with homes designed to last hundreds of years." ${ }^{1}$ Still, as a speculative builder, first-cost increases are a significant concern that the builder must balance with the goal for sustainable construction.

The key features of any viable solution package are a building envelope with continuous thermal, air, and moisture barriers and a simplified heating, ventilation, and air conditioning (HVAC) system designed to provide comfort as efficiently as possible. The basic cold climate package for these Singer Village Homes is: (1) flash and batt cavity insulation ( $\sim 2$ in. of closed-cell spray polyurethane foam and a 2-in. fiberglass batt to fill the remainder of the cavity) with exterior rigid insulation; (2) critical air sealing of penetrations, the ceiling plane, and rim/band joist area, (3) properly designed HVAC with efficient heating equipment; and (4) field performance testing and HVAC commissioning to ensure each home performs as designed. This package provides a robust building envelope that is durable and minimizes moisture concerns in the wall assemblies.

Based on Building Energy Optimization software energy modeling, this demonstration home is expected to save 30\% over a similar 2009 International Energy Conservation Code (IECC) compliant home and achieve a Home Energy Rating System Index of 45 without photovoltaics. This equates to an annual utility cost of $\$ 2,399$ and annualized energy-related costs of $\$ 3,023$. These estimates are based on typical occupants, but a user profile analysis showed that homeowner behavior could result in an annualized energy-related cost range of $\pm \$ 304$ depending on an occupant being classified as a "high energy user" versus a "low energy user." Ultimately, the actual performance of the home depends on the occupants.

The monthly out-of-pocket cost for homeowners was estimated to be lower for this home versus similar market alternatives (2009 IECC-compliant homes, 2003 IECC-compliant homes, and typical mid-90s homes). A cost of homeownership (mortgage, utilities, insurance, property taxes, maintenance, and tax benefits) analysis, based on costs provided by the builder, suggest that a homeowner of this demonstration home could anticipate \$130-\$1,657 in additional money saved

\footnotetext{
${ }^{1}$ http://energy.gov/eere/buildings/guidelines-participating-doe-zero-energy-ready-home
} 
each year over lower purchase price market alternatives. From the builder perspective, the incremental cost to achieve this DOE Zero Energy Ready Home was 5.5\% more for the builder, while adding an estimated $8.2 \%$ of additional value to the home.

From a holistic global perspective, the environmental benefit of this high performance home over 30 years is estimated to be equivalent to planting 1,641 fully mature trees, eliminating 502,531 miles driven by an average passenger car, or taking 38 passenger cars off the road for 1 year. This home was also awarded the 2013 Connecticut Zero Energy Challenge Award ${ }^{2}$ in the affordability category, as it had the lowest $\$ / \mathrm{ft}^{2}$ construction cost (just for structure from foundation up) of the 11 applicants.

2 https://www.youtube.com/watch?v=3yS6XuRxtaM 


\section{Introduction}

More and more builders are interested in "building right." What this exactly means and how to go about doing this can be challenging. Through its Zero Energy Ready Home program, the U.S. Department of Energy (DOE) is seeking to assist builders with a basic framework of a comprehensive solution package for "building right." This program incorporates building science research over the past two decades from DOE's Building America (BA) program. While primarily focused on energy efficiency, the program also incorporates quality of construction, durability, resiliency, indoor air quality, water conservation, and enabling homes to be zero netenergy ready.

The Consortium for Advanced Residential Buildings (CARB) has partnered with various builders throughout New York and Connecticut on Zero Energy Ready projects. To further evaluate the viability of builders implementing this program, CARB partnered with Brookside Development on the design and construction of a small development of seven high-efficiency, new construction homes on the old Singer Estate in Derby, Connecticut. This report covers the first home built in this development. The other homes will be equivalent homes with slight changes to floor plan and orientation to optimize the available solar resource. To allow for repeatability throughout the development, this demonstration home only used mature-market, commercially available systems to push toward the $30 \%$ source energy savings target, and meet the requirements of the DOE Zero Energy Ready Home program.

CARB worked with this builder partner in 2010 on two energy-efficient new construction market-rate prototypes (ENERGY STAR ${ }^{\circledR}$ v2.0 certified) in Connecticut. Those previous efficient homes included double-pane, low-e windows $(\mathrm{U}=0.30$, solar heat gain coefficient $[\mathrm{SHGC}]=0.28), \mathrm{R} \sim 40$ ceiling insulation (spray foam and blown cellulose), and $2 \times 4$ walls at 16 in. on center (o.c.) with open-cell spray polyurethane foam (ocSPF) in the stud cavity and continuous rigid exterior insulation of R-5.5 by using structural insulated sheathing. Air leakage testing of the envelope demonstrated achievement of $0.10 \mathrm{ACH}_{\text {nat }}$. For equipment, domestic hot water $(\mathrm{DHW})$ was provided by a natural gas tankless water heater (energy factor $[\mathrm{EF}]=0.82$ ), and a right-sized seasonal energy efficiency ratio (SEER) 18 air conditioner and 93\% annual fuel utilization efficiency (AFUE) natural gas condensing furnace were installed.
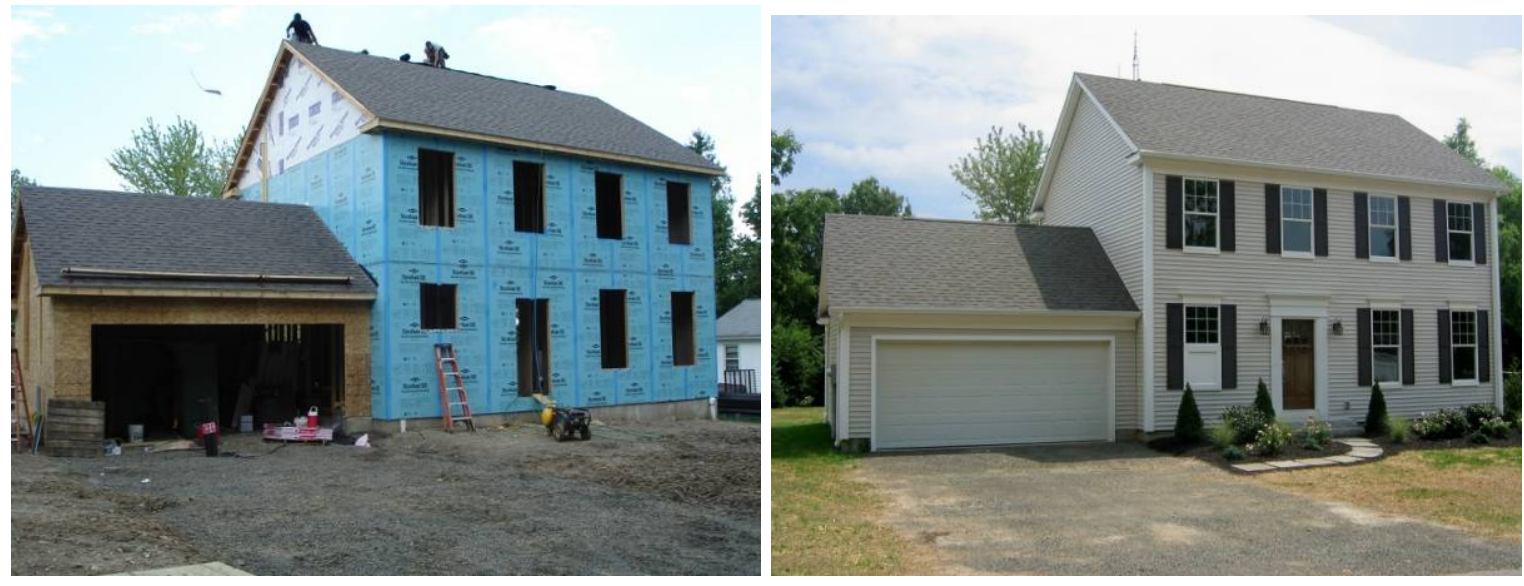

Figure 1. Previous Brookside Development home in Derby, Connecticut 
Figure 2 shows the estimated monthly homeownership expenses of one of these previous homes, 2 Frank Gates, as estimated by the builder. Even though the builder's home selling price may be slightly higher than a similar home built to current code (the 2009 International Energy Conservation Code [IECC]), the overall cost of homeownership is lower. A decent savings is estimated by the builder related to maintenance cost. It should be clear that the builder is making some assumptions on work that would need to be done on an existing home by a new buyer and that this high maintenance cost is only the first year of ownership. Even if this savings is removed from the analysis, the 2 Frank Gates home is still the better selection and this doesn't account for the improved comfort and durability that is associated with this energy-efficient home.

\begin{tabular}{|l|lr|rr|rr|}
\hline \multicolumn{1}{|c|}{} & \multicolumn{2}{|l|}{ 2 Frank Gates } & \multicolumn{2}{l|}{ 2010 Code Home } & \multicolumn{2}{l|}{ 2000 Code Home } \\
\hline Purchase Price (Value) & $\$$ & $369,900.00$ & $\$$ & $340,000.00$ & $\$$ & $299,000.00$ \\
\hline Down Payment & $\$$ & $73,980.00$ & $\$$ & $68,000.00$ & $\$$ & $59,800.00$ \\
\hline Loan Amount & $\$$ & $295,920.00$ & $\$$ & $272,000.00$ & $\$$ & $239,200.00$ \\
\hline Length of Mortgage (years) & & 30 & 30 & 30 \\
\hline Yearly Mortgage Interest Rate & & $4.20 \%$ & $4.36 \%$ & $4.36 \%$ \\
\hline
\end{tabular}

\begin{tabular}{|c|c|c|c|c|c|c|}
\hline Mortgage Amount & $\$$ & $1,447.10$ & $\$$ & $1,355.65$ & $\$$ & $1,192.17$ \\
\hline Insurance & $\$$ & 62.50 & $\$$ & 62.50 & $\$$ & 100.00 \\
\hline Property Tax & $\$$ & 516.67 & $\$$ & 500.00 & $\$$ & 500.00 \\
\hline Est. 1st Year Maintenance Cost (per month) & $\$$ & 16.67 & $\$$ & 50.00 & $\$$ & 249.17 \\
\hline Heating & $\$$ & 21.00 & $\$$ & 59.67 & $\$$ & 93.83 \\
\hline Water Heating & $\$$ & 7.83 & $\$$ & 10.75 & $\$$ & 13.50 \\
\hline Cooling & $\$$ & 11.42 & $\$$ & 32.33 & $\$$ & 47.83 \\
\hline Lighting \& Appliances & $\$$ & 97.67 & $\$$ & 162.50 & $\$$ & 175.50 \\
\hline Services & $\$$ & 29.42 & $\$$ & 29.42 & $\$$ & 29.42 \\
\hline Est. Tax Benefit (Based on 25\% Bracket) & $\$$ & $(404.00)$ & $\$$ & $(378.00)$ & $\$$ & $(220.00)$ \\
\hline ESTIMATED TOTAL MONTHLY COST: & $\$$ & $1,806.27$ & $\$$ & $1,884.82$ & $\$$ & $2,181.42$ \\
\hline
\end{tabular}

Figure 2. Estimated average monthly homeownership costs from builder's marketing literature

Now, Brookside Development is seeking to build an even more sustainable product that increases energy efficiency, while also addressing indoor air quality, water conservation, renewable-ready, and resiliency. As a spec builder, the first cost increases are a significant concern that the builder must balance with his desire for sustainable construction. 


\section{Research Goals}

The primary questions addressed by this research were:

- What solution package(s) can be readily implemented in a cold climate home to achieve DOE Zero Energy Ready Home certification?

- Is that solution package commercially viable? Where are opportunities to reduce costs in this solution package?

- What were the biggest challenges to complying with DOE Zero Energy Ready Home requirements? How were these challenges addressed by this builder? 


\section{Design Optimization}

The builder was not looking to impose significantly new construction techniques (e.g., high-R walls, decentralized heating, ventilation, and air conditioning [HVAC], ground-source heat pumps, $2 \times 6$ advanced framing, unvented attics) on his contractors. Therefore, the specification optimization primarily focused on optimizing the practices that this production builder could quickly incorporate into his construction process. For modeling optimization purposes, costs for the various measures are based on values from the National Residential Efficiency Measures Database, ${ }^{3}$ as pricing for each measure alternative was not available from the builder during the design process.

\subsection{Walls}

The builder's standard practice relied on a $2 \times 4$ wall system with open-cell spray polyurethane foam (ocSPF) in the stud cavities (R-4.4/in.). This equated to a wall assembly with a thermal resistance of R-12.4 (accounts for thermal bridging of wood studs) and contributed to achieveing building infiltration rates lower than $3.0 \mathrm{ACH}_{50}$. While this wall results in a well air-sealed wall assembly, there is potential concern for condensation on the sheathing in winter conditions. The use of structurally insulated sheathing (SIS) over this base wall package in the builder's last home minimized this concern. This translated to a wall assembly with a thermal resistance of R17.9 and contributed to achieving building infiltration rates lower than $2.0 \mathrm{ACH}_{50}$, but the builder had some issues with the SIS approach. ${ }^{4}$

Although some time was saved by using the SIS product, one of the disadvantages for this builder was the extra care required in properly fastening the panels to the studs. Even with an experienced installer, the staples occassionally missed the stud and had to be corrected (Figure 3). The builder found his standard practice of fastening oriented strand board (OSB) with nails to the studs to be less labor intensive than the approach needed with SIS. Another disadvantage for this builder was the reliance on seam tape to maintain a continuous barrier. When installing the sheathing and rigid insulation as separate products, the panels can be staggered so that the seams don't align and it's easier to maintain the continuous barrier. There was also a concern if there was a failure at one of the SIS tape seams that moisture could enter the wall assembly and the ocSPF insulation would soak up the moisture like a sponge. Therefore, the builder sought to investigate a more robust wall assembly for this project.

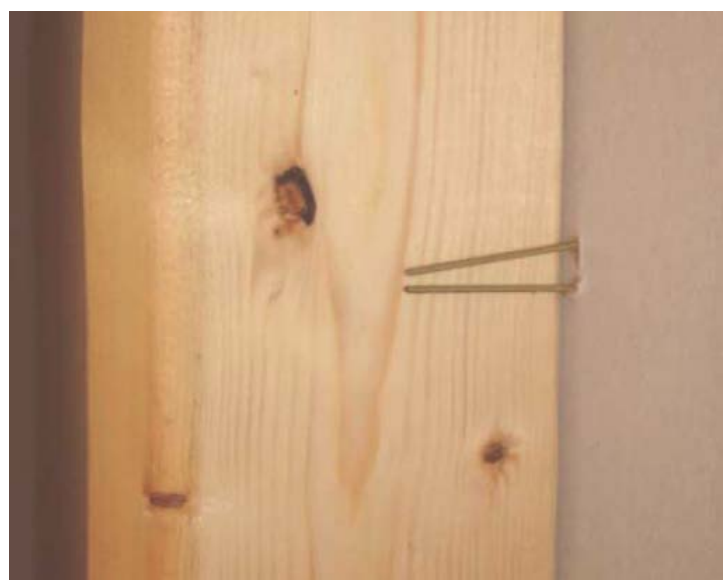

Figure 3. SIS staple missing the stud

Despite discussions on the benefits of advanced framing and a $2 \times 6$ wall system, the actual added costs (priced out by the builder to be $\$ 2,200$, as the increase in costs for the $2 \times 6$ studs was not offset by the savings in reduction in the number of studs by switching to $24 \mathrm{in}$. o.c. due

\footnotetext{
3 http://www.nrel.gov/ap/retrofits/

$4 \underline{\text { http://www.carb-swa.com/Collateral/Documents/CARB-SWA/Profiles/Brookside } \% 20 \text { Development } \% 20 \mathrm{Case} \% 20 \text { Study.pdf }}$
} 
to floor plan configuration) and the slight loss of finished floor area for these homes could not be justified.

For this development, the builder was interested in investigating the potential energy savings of a higher Rvalue wall versus first cost to determine if there was a cost benefit or if he was already at a point of diminishing returns in their wall assembly. Therefore, a flash and batt cavity insulation strategy with $\sim 2$ in. of ccSPF and a 2 in. fiberglass batt (FGB) to fill the remainder of the cavity was evaluated for his typical $2 \times 4$ framing (Figure 4 ). CARB has found numerous builders in the Northeast who prefer this insulation strategy. While the exterior insulation could potentially act as the air barrier if all the seams are taped, the use of the flash of ccSPF provides additional assurance of the air barrier continuity. Also, the exterior insulation was limited to 1 -in.

polyisocyanurate (R-6.5/in.) due to local material availability and the vinyl window flange on the builder's selected windows not allowing for thicker foam

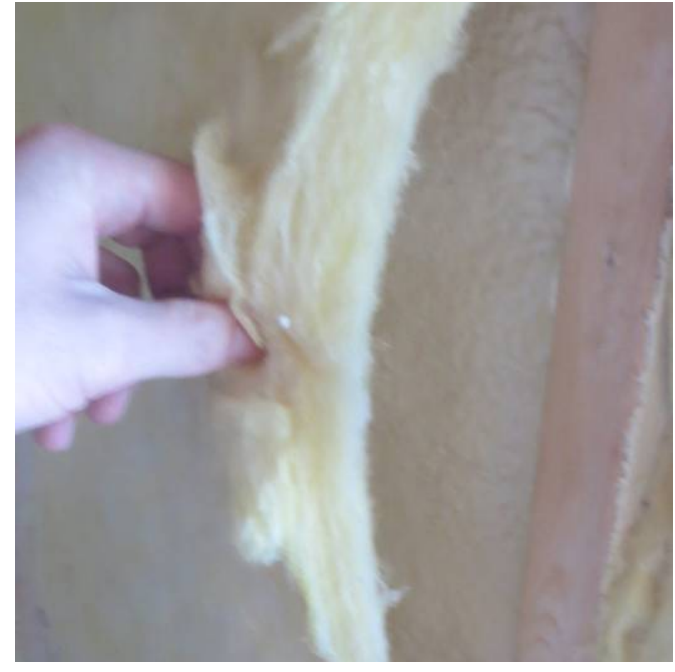

Figure 4. Flash and batt of $2 \times 4$ wall cavity applications without significant changes to window finshings. This translated to a wall assembly with a thermal resistance of R-20.7.

Though the builder was not switching to $2 \times 6$ framing, a $2 \times 6$ wood framed wall at 24 in. o.c. with ocSPF filling the wall cavity (R-24.5) and 1.5 in. of exterior insulation over the structural sheathing was included for comparison purposes (along with the builder's past wall assemblies and a code compliant assembly) in the energy modeling. This equated to a wall assembly with a thermal resistance of R-24.1. A higher wall cavity R-value of 31.9 could have been achieved by using closed-cell spray polyurethane foam (ccSPF), but is typically not applied to the full depth of the cavity to avoid difficulty of trimming the insulation to allow a smooth application of the sheetrock. Realistically, the ccSPF would only be sprayed to roughly 4 in. in depth or R-23.2 (so energy performance is comparable to the ocSPF case that was modeled). While ccSPF is vapor impermeable (unlike ocSPF) at this thickness, it is significantly more expensive.

Figure 5 provides the results of the wall optimization energy modeling versus a code compliant wall ( $2 \times 4$ wall with R-13 cavity insulation and R-5 rigid insulation on exterior). A reduction of $2 \mathrm{ACH}_{50}$ from code required infiltration levels was assumed for the cases with spray foam insulation in the wall cavities. In general the later three wall assemblies are fairly comparable in terms of energy performance, but the last option that utilizes ccSPF is the most robust assembly based on water/moisture durability and therefore, was selected by the builder.

According to the builder, the flash and batt wall cavity insulation approach would cost roughly $\$ 2,800$ more than standard R-13 FGBs, but the builder was fine with this due to a higher confidence in the air sealing and overall performance of the assembly. In addition, the builder estimated that the added market value of the energy savings, comfort, quietness, and cleanliness from using the spray foam would be at least $\$ 5,000$. 


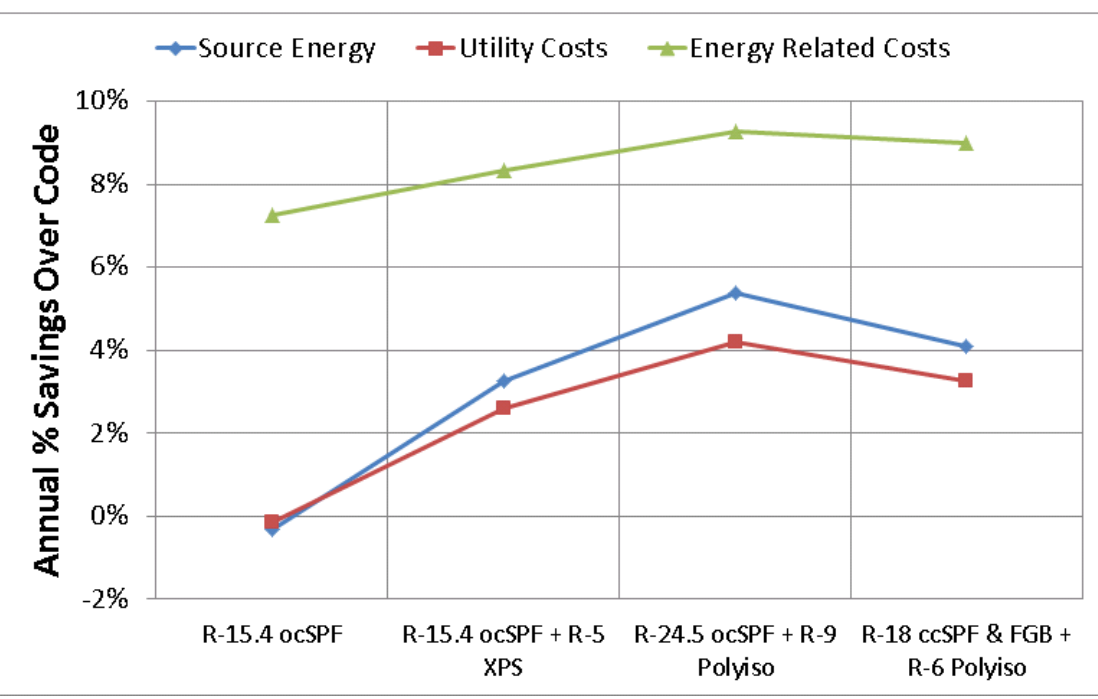

Figure 5. Different wall insulations considered by the builder

\subsection{Foundation}

Insulation for foundations is typically lower because the ground temperature is more constant than outdoor winter air temperatures. However, the top above-grade portions of basement walls are often exposed to outdoor air. During winter conditions, the first few feet of earth below grade also become much colder than earth at the bottom of a typical basement. While it was recommended to provide full height foundation insulation to prevent any potential for thermal short circuiting into the wall and up behind the insulation, the builder selected to go with the half wall R-9.8 polyisocyanurate. The thinking was that this could be extended to full height later on if desired by the future occupants. The half wall insulation was extended to at least $3 \mathrm{ft}$ below grade (due to the grade, this was $4 \mathrm{ft}$ from the top on half the basement walls and $5 \mathrm{ft}$ for the other half). The builder made sure to air seal all edges (especially the bottom) of the insulation to the foundation wall, so that moisture wouldn't have a path to get behind the insulation to the cooler exposed portion of the foundation and condense. The money saved from half wall foundation insulation $(\sim 1,600)$ was put into air sealing the rim/band joist area and the transition from sill to foundation wall with ccSPF $(\sim \$ 80)$, as shown in Figure 6.

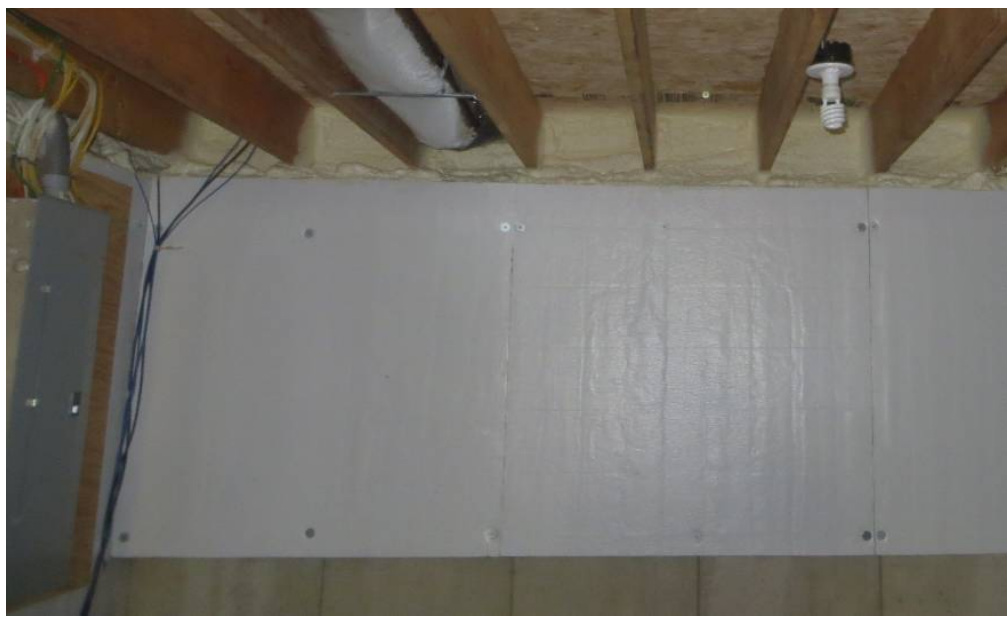

Figure 6. Air sealing critical transition between sill plate and foundation wall 


\subsection{Air Sealing}

In many regards, airtightness is more important than the overall thermal resistance of the building envelope. Of course, insulation is beneficial, but it is effective only if air sealed. Based on the Building Energy Optimization (BEopt) analysis (Figure 7), there is a slight diminish in return for airtightness levels below $2 \mathrm{ACH}_{50}$. Therefore, the strategies for air sealing the walls, $\mathrm{rim} / \mathrm{band}$ joists, and ceiling plane were selected based on CARB's past experience to achieve a building tightness of $2 \mathrm{ACH}_{50}$.

The wall and foundation air sealing strategies have been discussed in Section 3.1 and 3.2, respectively. For the ceiling plane, spot-applied spray foam was used over all partitions, openings, and seams (Figure 8) prior to blown cellulose being installed. This critical seal of the ceiling cost $\$ 1,800$, but the builder estimates that this measure added $\$ 5,000$ of value in energy savings and comfort.

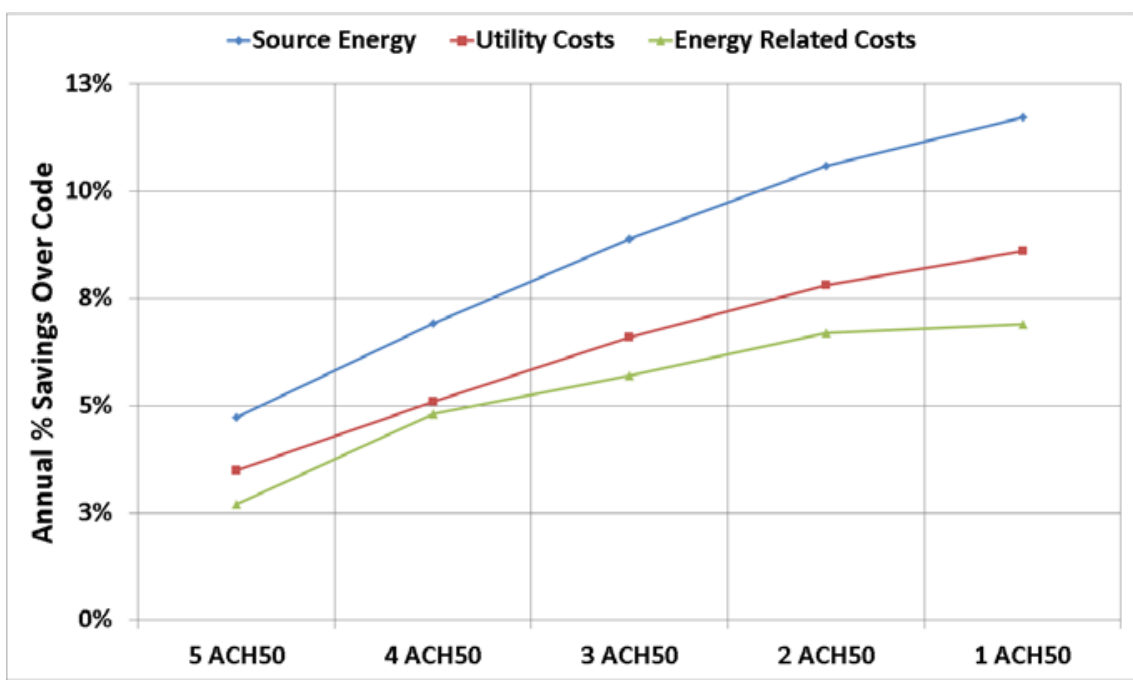

Figure 7. Analysis of infiltration impact on building performance

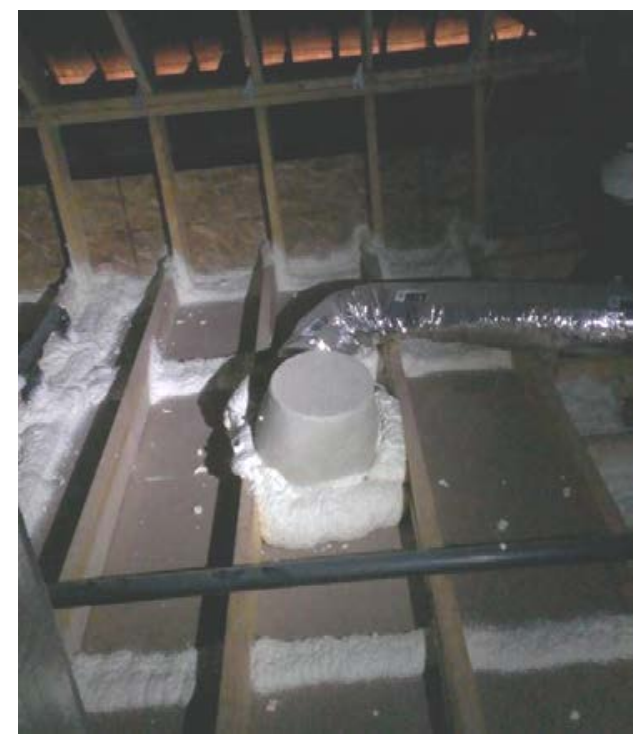

Figure 8. Critical air seal of ceiling plane 


\subsection{Mechanical Ventilation}

Energy recovery ventilators (ERVs) are the most efficient type of whole-house ventilation because of their energy recovery capabilities (Figure 9); however, the builder decided to go with the cheaper exhaust-only ventilation strategy. The continuous whole-house ventilation rate was split between the upstairs and downstairs full bathrooms. The cost of this whole-house ventilation solution (two exhaust fans with built-in continuous and delay off controls and motion detectors for override control) was $\$ 400$, as opposed to $\$ 1,850$ for an ERV. With the choice of the exhaust fan, the building meets the ASHRAE 62.2-2010 minimum whole-building ventilation requirement while the builder utilized the \$1,250 worth of savings toward offsetting the added cost of air sealing the building envelope.

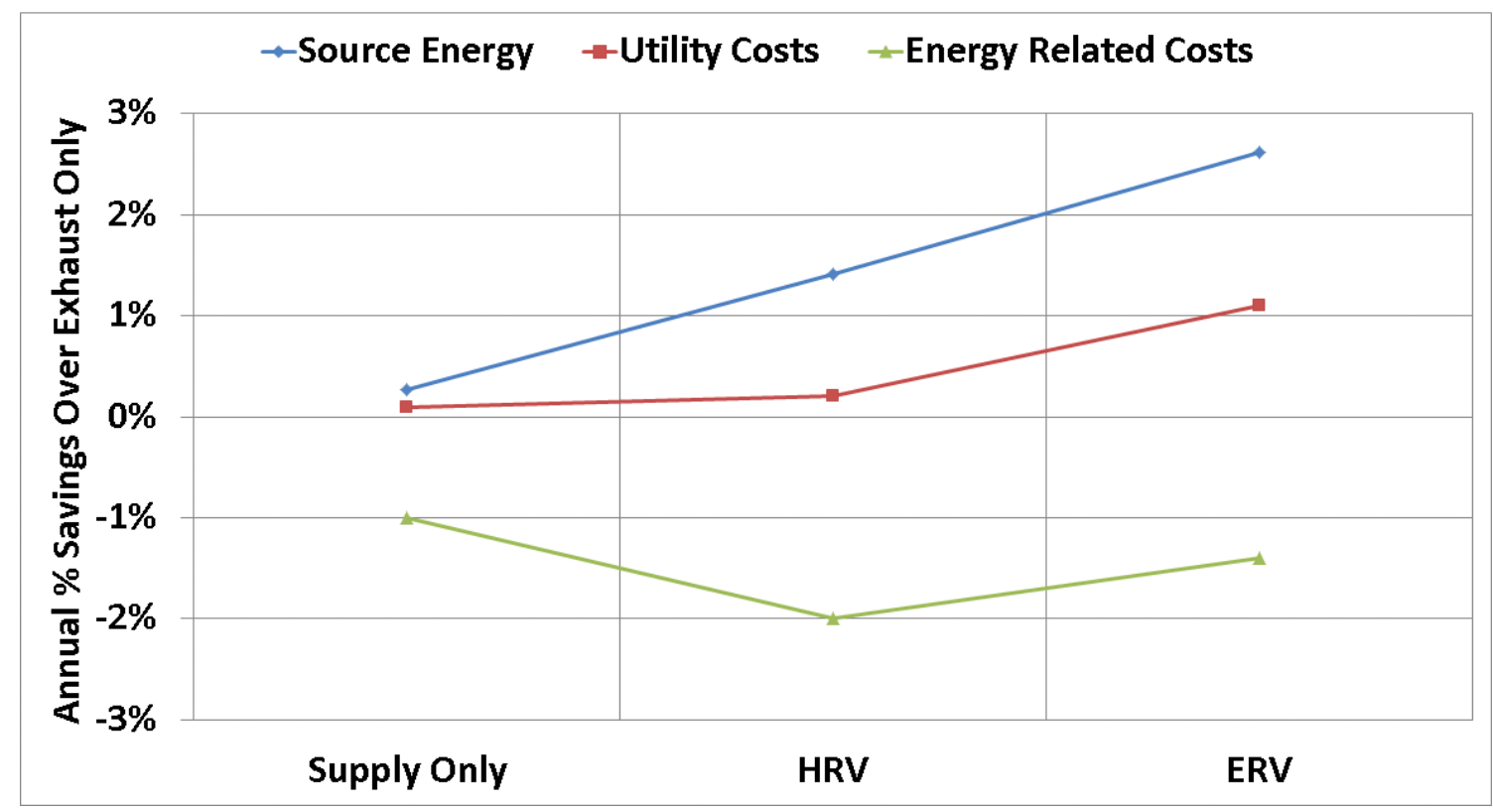

Figure 9. Performance comparison of mechanical ventilations systems

\subsection{Space Conditioning Equipment}

Although the home has natural gas available for the water heater, clothes dryer, and cooking range, the builder wanted to investigate providing as much of the space heating with electricity that could be offset with onsite solar photovoltaic (PV) generation. Efficient all-electric heating options are available, but central distribution systems, such as ground-source heat pump and inverter-driven air-source heat pumps (ASHPs), can be expensive. For the past several years, this builder has been offering a traditional ASHP with a condensing furnace backup. Unfortunately, there was an oversight in the equipment selection.

When the system was only intended to be a gas-furnace (96 AFUE) with air conditioner, CARB had recommended that the builder save money on the air conditioner by not going with a high efficiency unit due to the minimal cooling load for this building and climate zone. When the builder decided to go with the dual-fuel system, an ASHP with a cooling SEER of 14 was selected without realizing the negative impact this would have on the heating season performance factor (HSPF), which was rated at only 8.0. This resulted in it being more cost effective to simply run the gas furnace with an AFUE of 96 unless outdoor temperatures are 
above $50^{\circ} \mathrm{F}$ (Figure 10 ). Heating loads are fairly minimal at $50^{\circ} \mathrm{F}$. The varying cost in fuel cost resulted in this dual-fuel strategy being essentially cost neutral to just a condensing furnace; only a $\$ 44$ difference. Still, source energy was reduced by an estimated $8.6 \%$ over just a condensing furnace. With an added cost of $\$ 1,400$ over a standard air conditioner, it is unlikely the builder will incorporate the dual-fuel heat pump in the remainder of the community. If he does continue the use of the dual-fuel heat pump, a higher efficiency unit (9+ HSPF) will be specified.

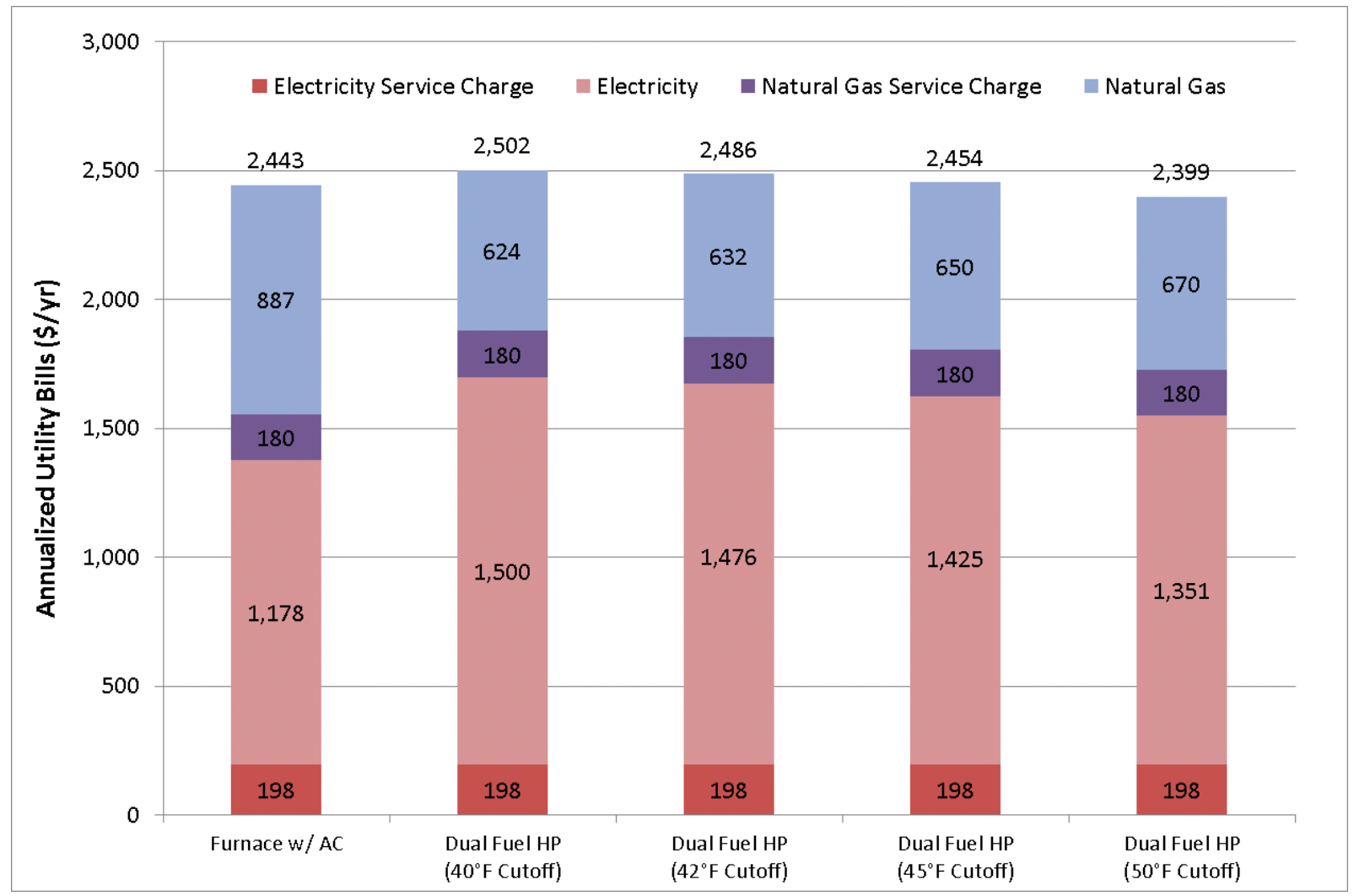

Figure 10. Utility cost analysis for various heat pump cutoff temperatures

\subsection{Sizing the Photovoltaic System}

Although the PV incentives provide an opportunity to provide deep energy savings over the BA benchmark, the local utility will not rebate electricity generation in excess of the annual consumption. As a result, the PV system must be properly sized to match the electricity load of the house. Local PV incentives are $\$ 1.75 / \mathrm{W}$ up to a $5-\mathrm{kW}$ system and reduce to $\$ 0.55 / \mathrm{W}$ up to a $10-\mathrm{kW}$ system. The builder originally intended to install a 5-kW PV system to obtain the highest incentive per Watt. Later discussions with PV contractors suggested that adding an additional 2 $\mathrm{kW}$ above the $5 \mathrm{~kW}$ would be at a marginal rate in which the $\$ 0.55 / \mathrm{W}$ incentive may still make sense. Moreover, looking at Figure 11, it can be observed that the 7-kW PV system better meets the electricity demand of the design with the dual-fuel heat pump for all scenarios. As the local PV incentives can be obtained only by a homeowner, the builder is offering to work with the homeowner to have the desired PV system size installed at the closing. 


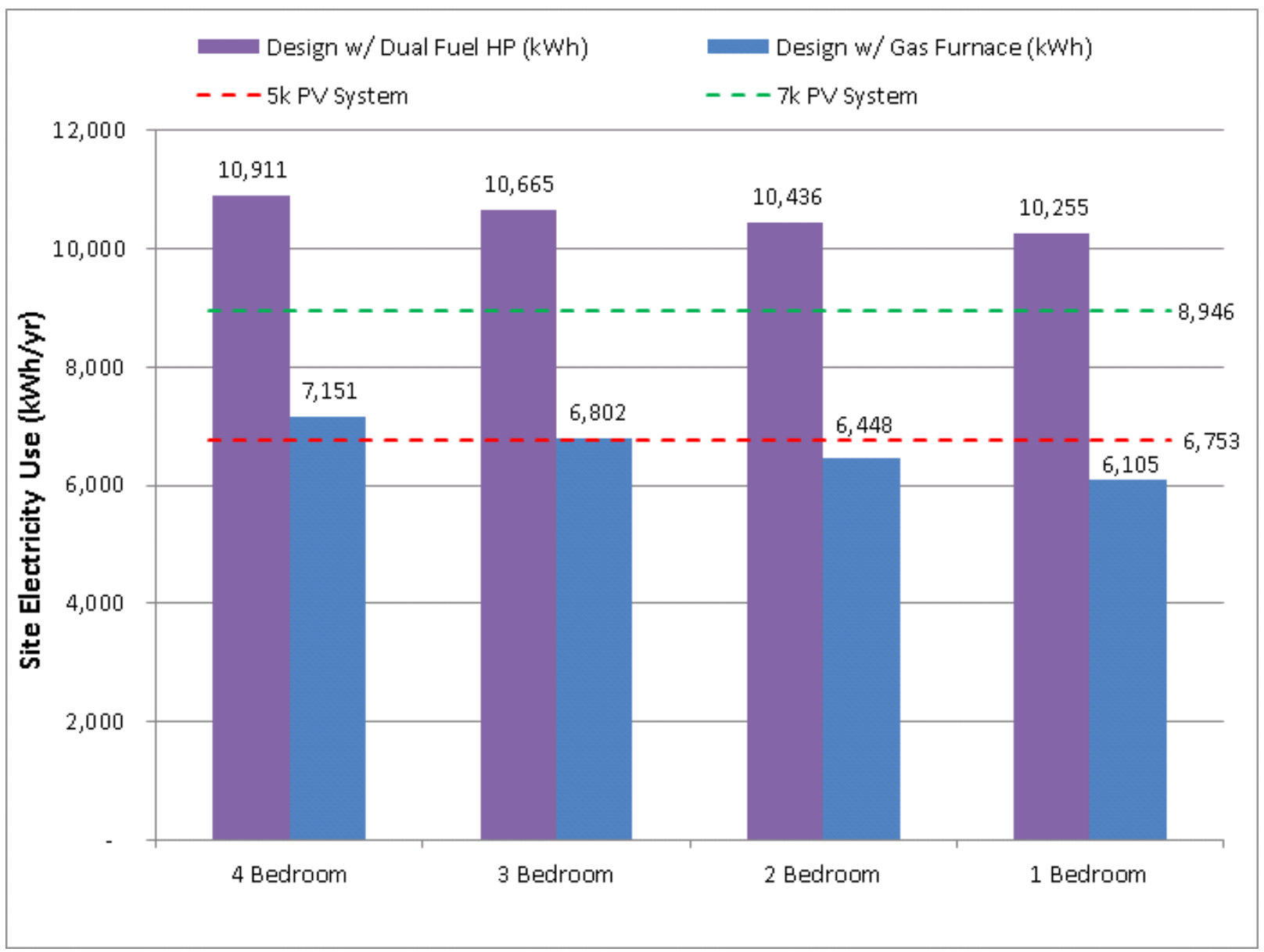

Figure 11. Estimating appropriate PV system size to offer to homeowners

\subsection{Whole-Building Performance}

The builder aimed to achieve compliance with the DOE Zero Energy Ready Home program through efficiency improvements in mechanical equipment and the building enclosure. To achieve deeper energy reductions, PV will be offered to homeowners as a means to offset the majority of remaining electricity loads in the house. A BEopt 2.1 optimization simulation was performed for a variety of envelope and equipment features, as shown in Table 1. The optimization was performed without PV incentives. 
Table 1. BEopt Simulation Options

\begin{tabular}{|c|c|}
\hline Options Category & Simulated Options \\
\hline Walls & $\begin{array}{c}\text { R-13 FGBs, Gr-1, } 2 \times 4,16 \text { in. o.c. } \\
\text { R-15-4 ocSPF, Gr-1, } 2 \times 4,16 \text { in. o.c. } \\
\text { R-18 } 2 \text { in. ccSPF }+ \text { compressed } 2 \text { in. FGB, Gr-1, } 2 \times 4,16 \text { in. o.c. } \\
\text { R-21 FGBs, Gr-1, } 2 \times 6,24 \text { in. o.c. } \\
\text { R-24.5 ccSPF, Gr-1, } 2 \times 4,16 \text { in. o.c. }\end{array}$ \\
\hline Wall Sheathing & $\begin{array}{l}\text { OSB, R-6 polyisocyanurate } \\
\text { OSB, R-9 polyisocyanurate } \\
\text { OSB, R-12 polyisocyanurate }\end{array}$ \\
\hline Attic & $\begin{array}{l}\text { Ceiling R-38 cellulose, vented } \\
\text { Ceiling R-49 cellulose, vented } \\
\text { Ceiling R-60 cellulose, vented }\end{array}$ \\
\hline Unfinished Basement & $\begin{array}{l}\text { Half wall, R-9 polyisocyanurate } \\
\text { Half wall, R-13 polyisocyanurate } \\
\text { Whole wall, R-9 polyisocyanurate } \\
\text { Whole wall, R-13 polyisocyanurate }\end{array}$ \\
\hline Windows & $\begin{array}{l}\text { Double-pane, low-e, insulated frame, } U=0.29, \mathrm{SHGC}=0.31 \\
\text { Triple-pane, low-e, insulated frame, } \mathrm{U}=0.19, \mathrm{SHGC}=0.29\end{array}$ \\
\hline Air Leakages & $\begin{array}{l}3.0 \mathrm{ACH}_{50} \\
2.0 \mathrm{ACH}_{50} \\
1.5 \mathrm{ACH}_{50} \\
1.0 \mathrm{ACH}_{50}\end{array}$ \\
\hline Ventilation & $\begin{array}{l}\text { Exhaust only, } 100 \% \text { ASHRAE } 62.2-2010 \\
\text { ERV, } 72 \% \text { efficient, } 100 \% \text { ASHRAE } 62.2-2010\end{array}$ \\
\hline Refrigerator & ENERGY STAR \\
\hline Cooking Range & Gas \\
\hline Dishwasher & ENERGY STAR \\
\hline Clothes Washer & ENERGY STAR \\
\hline Clothes Dryer & Gas \\
\hline Lighting & $\begin{array}{l}34 \% \text { fluorescent } \\
60 \% \text { fluorescent } \\
100 \% \text { fluorescent }\end{array}$ \\
\hline Heating Equipment & 96 AFUE \\
\hline Cooling Equipment & $\begin{array}{c}\text { SEER } 13 \\
\text { SEER } 14.5 \\
\text { SEER } 16 \text { (two stage) } \\
\text { SEER } 19 \text { (two stage) }\end{array}$ \\
\hline Ducts & In conditioned space \\
\hline Water Heater & $\begin{array}{l}\text { Gas tankless } \\
\text { Gas tankless, condensing } \\
\text { HPWH, } 50 \text { gal }\end{array}$ \\
\hline PV & $\begin{array}{l}\text { None } \\
3 \mathrm{~kW} \\
4 \mathrm{~kW} \\
5 \mathrm{~kW}\end{array}$ \\
\hline
\end{tabular}


For the economic analysis, the economic values in Table 2 were used per the BA House Simulation Protocols requirements (Hendron and Engebrecht 2010). The effects of other values for mortgage interest and fuel escalation rates were explored in further detail and are discussed in Appendices A and B.

Table 2. Inputs of Economic Analysis

\begin{tabular}{|c|c}
\hline Economic Variables & Modeling Inputs \\
\hline Project Analysis Period & 30 years \\
Inflation Rate & $3 \%$ \\
\hline Discount Rate (Real) & $3 \%$ \\
Loan Period & 30 years \\
Loan Interest Rate & $7 \%$ \\
\hline Marginal Income Tax Rate & $28 \% / 0 \%$ \\
(Federal/State) & $\$ 0.19 / \mathrm{kWh}+\$ 16.50$ monthly charge \\
\hline Electricity Rate* & $\$ 1.37 /$ therm $+\$ 15.00$ monthly charge \\
Natural Gas Rate* & $0 \%$ \\
Fuel Escalation Rate & \\
\hline * Local rates &
\end{tabular}

The design was modeled without PV, with PV and no incentives, and with PV and incentives (a federal $30 \%$ tax credit and a state rebate of $\$ 1.75 / \mathrm{W})$. All points from the optimization and design run are shown in Figure 12.

-Min. Cost Curve Benchmark $\Delta$ Design w/o PV $\Delta$ Design w/PV $\Delta$ Design w/ PV + Incentives As Built

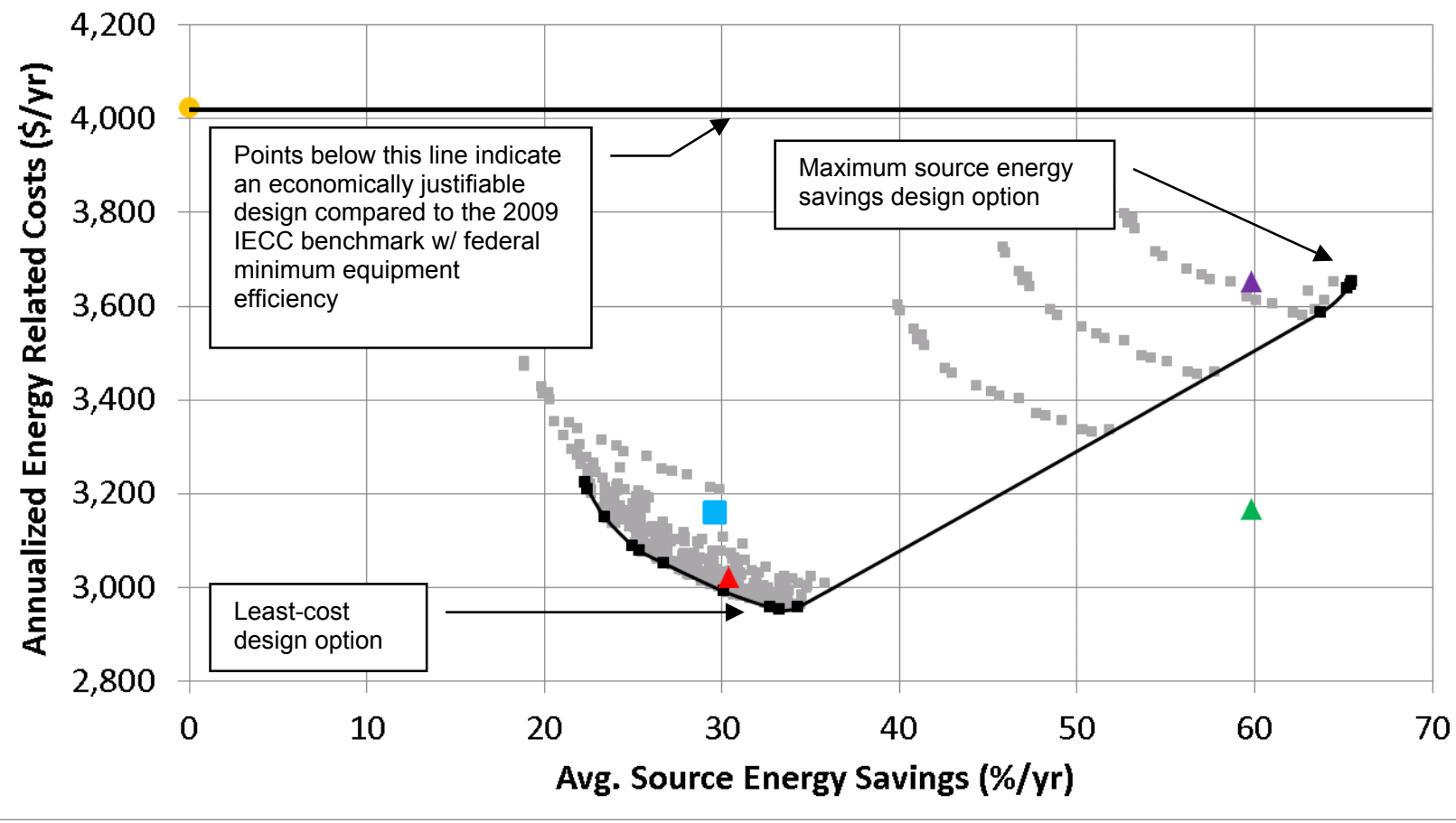

Figure 12. BEopt optimization analysis with proposed design and as-built home 
The final design solution package that was estimated to achieve $30.5 \%$ energy savings over a typical code-compliant home is provided in Table 3.

Table 3. Final Design Specifications Summary

\begin{tabular}{|c|c|c|}
\hline Component & 2009 IECC-Compliant Home & Final Design Solution Package \\
\hline $\begin{array}{l}\text { Foundation } \\
\text { Insulation }\end{array}$ & Whole wall, R-10 insulation & Half wall, R-9 polyisocyanurate \\
\hline $\begin{array}{l}\text { Above-Grade } \\
\text { Wall Assembly }\end{array}$ & $\begin{array}{l}\text { R-13 cavity insulation, } 2 \times 4,16 \text { in. } \\
\text { o.c., R-5 exterior insulation }\end{array}$ & $\begin{array}{l}\text { R-18 2-in. ccSPF and 2-in. } \\
\text { compressed FGB, } 2 \times 4,16 \text { in. o.c. } \\
\text { OSB, R-6 polyisocyanurate }\end{array}$ \\
\hline $\begin{array}{l}\text { Ceiling } \\
\text { Insulation }\end{array}$ & R-38 insulation & R-60 blown cellulose \\
\hline $\begin{array}{l}\text { Window } \\
\text { Glazing }\end{array}$ & U-0.35/SHGC-0.44 & $\begin{array}{l}\text { Dual pane, low-e windows with vinyl } \\
\text { frame (U-0.28/SHGC-0.27) }\end{array}$ \\
\hline Infiltration & $7 \mathrm{ACH}_{50}$ & $2.0 \mathrm{ACH}_{50}$ \\
\hline Ventilation & Exhaust-only & Energy recovery ventilator \\
\hline $\begin{array}{l}\text { Heating } \\
\text { System }\end{array}$ & 78 AFUE natural gas furnace & $\begin{array}{l}96 \text { AFUE natural gas condensing, } \\
\text { two-stage furnace }\end{array}$ \\
\hline $\begin{array}{l}\text { Cooling } \\
\text { System }\end{array}$ & SEER 13 air conditioner & SEER 14.5 air conditioner \\
\hline Ductwork & R-6, $15 \%$ total leakage & R-6, 5\% total leakage \\
\hline Water Heating & $\begin{array}{c}\text { 0.59 EF natural gas 50-gal storage } \\
\text { water heater }\end{array}$ & $\begin{array}{l}\text { 0.94 EF natural gas condensing } \\
\text { tankless water heater }\end{array}$ \\
\hline Lighting & $34 \%$ fluorescent & $100 \%$ fluorescent \\
\hline Appliances & $\begin{array}{l}\text { ENERGY STAR refrigerator, } \\
\text { dishwasher, clothes washer, and } \\
\text { exhaust fans. Gas cooking range } \\
\text { and clothes dryer. }\end{array}$ & $\begin{array}{c}\text { ENERGY STAR refrigerator, } \\
\text { dishwasher, clothes washer, and } \\
\text { exhaust fans. Gas cooking range and } \\
\text { clothes dryer. }\end{array}$ \\
\hline
\end{tabular}

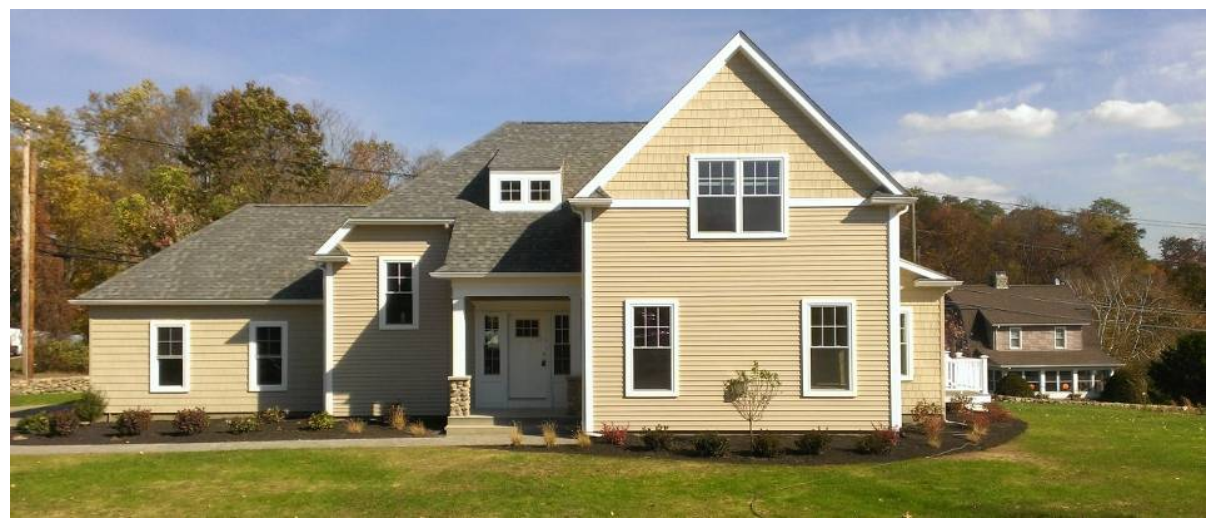

Figure 13. The first home in the Singer Estate Development

The only difference in the design and as-built specifications was the switch to an exhaust-only whole-house ventilation strategy and the addition of the dual-fuel heat pump. This resulted in a slight drop in the source energy savings to $29.6 \%$ over a typical code-compliant home. The 
difference between the final design solution package and the least-cost design $(33.4 \%$ source energy savings over code) based on the BEopt optimization is provided in Table 4.

Table 4. Final Design Solution Package Comparison to BEopt Least-Cost Package

\begin{tabular}{|c|c|c|}
\hline Component & Final Design Solution Package & BEopt Least-Cost Package \\
\hline $\begin{array}{l}\text { Above-Grade } \\
\text { Wall Assembly }\end{array}$ & $\begin{array}{l}\text { R-18 2-in. ccSPF and } 2 \text { in. } \\
\text { compressed FGB, } 2 \times 4,16 \text { in. o.c., } \\
\text { R-6 polyisocyanurate }\end{array}$ & $\begin{array}{l}\mathrm{R}-24.5 \text { ccSPF, Gr- } 1,2 \times 4,16 \text { in. } \\
\text { o.c., R-9 polyisocyanurate }\end{array}$ \\
\hline $\begin{array}{l}\text { Foundation } \\
\text { Insulation }\end{array}$ & Half wall, R-9 polyisocyanurate & Whole wall, R-12 polyisocyanurate \\
\hline Infiltration & $2 \mathrm{ACH}_{50}$ & $1 \mathrm{ACH}_{50}$ \\
\hline Ventilation & ERV & Exhaust-only \\
\hline Cooling System & SEER 14.5 air conditioner & SEER 16 (2 Stage) air conditioner \\
\hline Water Heating & $\begin{array}{l}\text { 0.94 EF natural gas condensing } \\
\text { tankless water heater }\end{array}$ & $\begin{array}{c}0.82 \text { EF natural gas tankless water } \\
\text { heater }\end{array}$ \\
\hline
\end{tabular}

This least-cost alternative was not selected for the following reasons:

- Filling the entire $2 \times 4$ cavity with ccSPF would have been time consuming and labor intensive to trim ccSPF flush to studs, so the flash and batt approach was determined to still allow energy goals to be met while making implementation easier. Similarly, R-6 polyisocyanurate was chosen for the wall sheathing because it was easier to detail, and readily available from the local distributer. The builder felt that the 1.5 -in. exterior rigid insulation would have complicated building details around openings and the value of the additional 0.5 in. of insulation was not significant enough to warrant the higher insulation level.

- Half wall foundation insulation was chosen so that costs related to air sealing the $\mathrm{rim} / \mathrm{band}$ joists and ceiling plane could be offset.

- As space cooling loads are not significant in this climate zone, a single-stage SEER 14 air conditioner was selected to minimize first cost and simplify the mechanical systems. In addition, the builder's cost for a two-stage system was nearly twice what BEopt was assuming in the cost analysis.

- The builder's cost difference between a condensing and non-condensing tankless water heater was roughly $\$ 100$ plus a condensate pump. Therefore, the builder felt there was suitable marketing value in specifying the

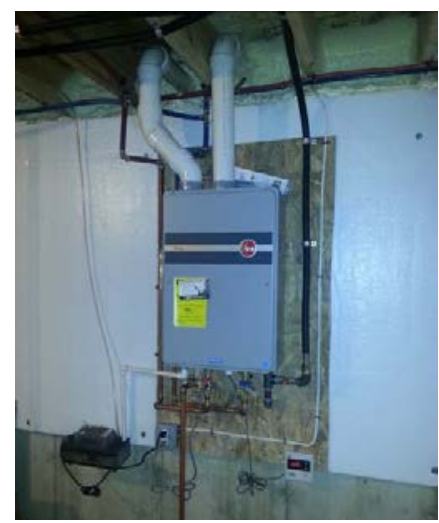

Figure 14. Condensing tankless water heater condensing tankless water heater.

Figure 15 shows the cumulative percentage energy savings (line graph) resulting from adding each improvement measure of the final design solution package and the impact on the wholehouse source energy use (bar graph). Based on past experience in homes that did only roof air sealing versus roof and walls, the reduction in building infiltration over a code compliant home 
from air sealing was split evenly between the attic insulation (2.5 $\mathrm{ACH}_{50}$ reduction) and wall insulation (2.5 $\mathrm{ACH}_{50}$ reduction) measures. The measures have been sequenced in terms of greatest individual impact when applied to a code-compliant home. A corresponding Home Energy Rating System (HERS) Index has also been provided with each incremental measure. For builders who are not able to go to the level of efficiency that this home has pursued, this sequencing of measures by impact can be used as a guide on where to allocate money to maximize the return on investment (ROI). 


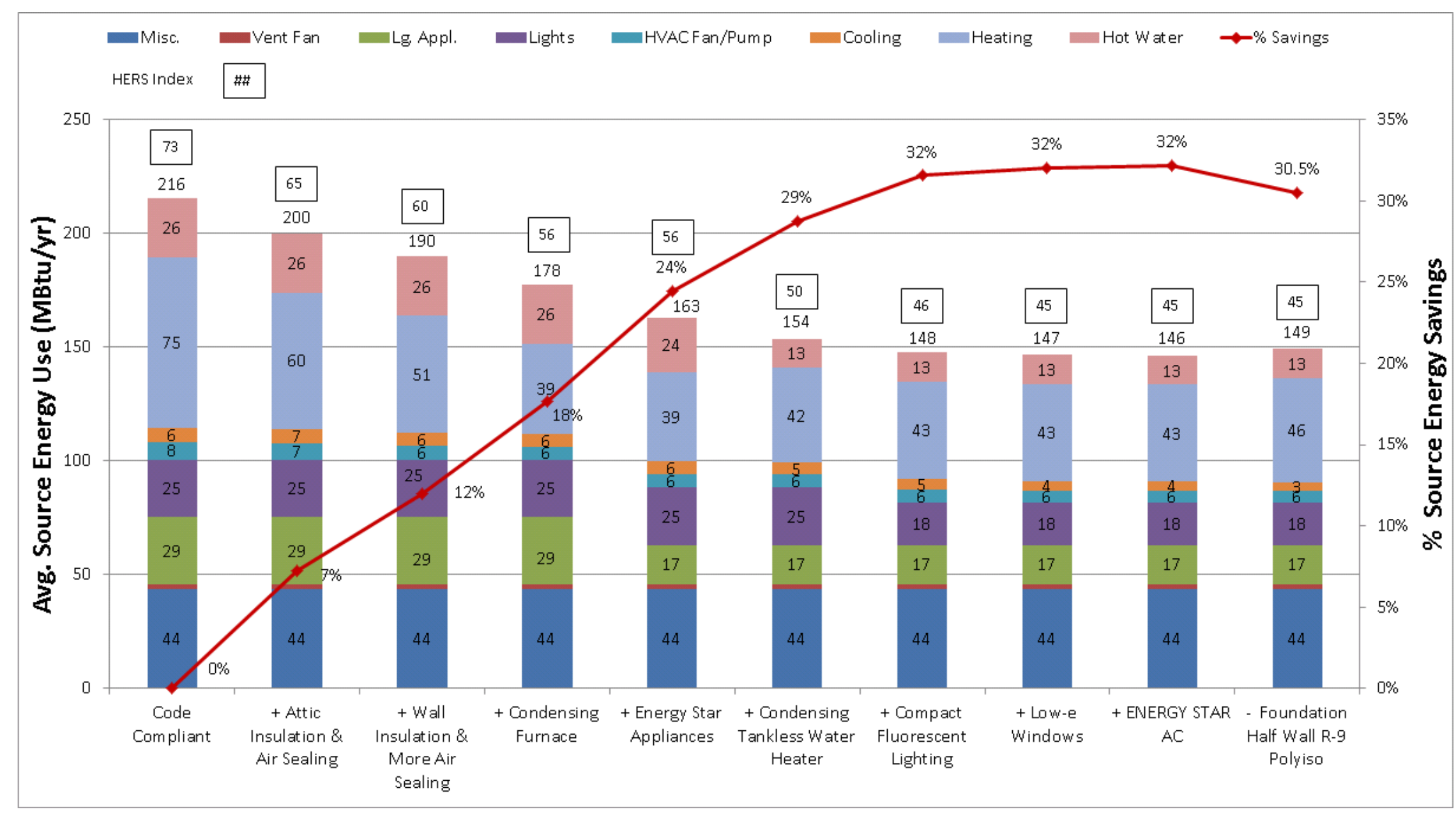

Figure 15. Cumulative contribution to total energy savings by measure and end use 
When performing energy analysis, the occupant and appliance profiles are based on national averages. Below is a discussion on the effects of three different user profiles and how they affect annualized energy related cost (AERC) and utility bills. The "high energy user" and "low energy user" user profile were created by adjusting heating and cooling temperature set points by $\pm 2^{\circ} \mathrm{F}$ and miscellaneous electric, gas, and hot water load multipliers by $25 \%$ from that of the average energy user. The summary of the modeling input parameters and their values for each user profile are shown in Table 5.

Table 5. Defining User Profiles in Energy Model

\begin{tabular}{c|c|c|c}
\hline Input Parameter & $\begin{array}{c}\text { High Energy } \\
\text { User }\end{array}$ & $\begin{array}{c}\text { Average Energy } \\
\text { User }\end{array}$ & $\begin{array}{c}\text { Low Energy } \\
\text { User }\end{array}$ \\
\hline Heating Set Point $\left({ }^{\circ} \mathbf{F}\right)$ & 73 & 71 & 69 \\
Cooling Set Point $\left({ }^{\circ}\right.$ F) & 74 & 76 & 78 \\
\hline Misc. Electric Loads Multiplier & 1.25 & 1.00 & 0.75 \\
Misc. Gas Loads Multiplier & 1.25 & 1.00 & 0.75 \\
\hline Misc. DHW Loads Multiplier & 1.25 & 1.00 & 0.75 \\
\hline
\end{tabular}

Table 6 shows that annualized utility cost for the high energy user is about $\$ 607$ more than that of the low energy user. This user profile analysis shows the impact that homeowner behavior has on the energy and cost savings expected from a high performance home. Ultimately, the actual performance of the home depends on the occupants.

Table 6. Utility Cost and Percentage Energy Savings for the Three User Profiles

\begin{tabular}{c|c|c|c|c|c}
\hline \multirow{2}{*}{} & \multicolumn{3}{|c|}{$\begin{array}{c}\text { Annualized Utility Cost } \\
\text { (\$/year) }\end{array}$} & \multicolumn{2}{c}{$\begin{array}{c}\text { Source Energy Savings } \\
\text { (\%) }\end{array}$} \\
\cline { 2 - 6 } & Code & Design w/o PV & Design w/ PV & Design w/o PV & Design w/ PV \\
\hline $\begin{array}{c}\text { High Energy } \\
\text { User }\end{array}$ & $\$ 3,716$ & $\$ 2,757$ & $\$ 1,749$ & $29.7 \%$ & $55.6 \%$ \\
$\begin{array}{c}\text { Average } \\
\text { Energy User } \\
\text { Low Energy } \\
\text { User }\end{array}$ & $\$ 3,334$ & $\$ 2,443$ & $\$ 1,436$ & $30.5 \%$ & $59.8 \%$ \\
\hline
\end{tabular}




\section{Implementation of a U.S. Department of Energy Zero Energy Ready Home}

The programmatic requirements of the DOE Zero Energy Ready Home certification program are listed in Table 7. Requirement checklists for this certification program provided a lot of thirdparty verification throughout the construction process, but the builder must be committed to a quality project to achieve success. Some key building envelope details for successful compliance are highlighted in the Figure 16 photo collage.

\section{Table 7. DOE Zero Energy Ready Home Program Requirements}

(Source: Challenge 2012)

\begin{tabular}{|c|c|}
\hline Area of Improvement & Mandatory Requirements \\
\hline $\begin{array}{l}\text { ENERGY STAR for } \\
\text { Homes Baseline }\end{array}$ & $\checkmark$ Certified under ENERGY STAR Qualified Homes Version 3 \\
\hline Envelope & $\begin{array}{l}\square \text { Fenestrations shall meet or exceed latest ENERGY STAR } \\
\text { requirements } \\
\square \text { Ceiling, wall, floor, and slab insulation shall meet or exceed } \\
2012 \text { IECC levels }\end{array}$ \\
\hline Duct System & $\begin{array}{l}\square \text { Ducts located within the home's thermal and air barrier } \\
\text { boundary }\end{array}$ \\
\hline Water Efficiency & $\begin{array}{l}\square \text { Hot water delivery systems shall meet efficient design } \\
\text { requirements [no more than } 0.5 \text { gals in distribution system] }\end{array}$ \\
\hline $\begin{array}{l}\text { Lighting and } \\
\text { Appliances }\end{array}$ & $\begin{array}{l}\square \text { All installed refrigerators, dishwashers, and clothes washers are } \\
\text { ENERGY STAR qualified } \\
\square \text { 80\% of lighting fixtures are ENERGY STAR qualified or } \\
\text { ENERGY STAR lamps (bulbs) in minimum of } 80 \% \text { of sockets } \\
\square \text { All installed bathroom ventilation and ceiling fans are ENERGY } \\
\text { STAR qualified }\end{array}$ \\
\hline Indoor Air Quality & $\begin{array}{l}\square \text { EPA Indoor airPLUS Verification Checklist and Construction } \\
\text { Specifications }\end{array}$ \\
\hline Renewable Ready & $\begin{array}{l}\square \text { EPA Renewable Energy Ready Home Solar Electric Checklist } \\
\text { and Specifications } \\
\square \text { EPA Renewable Energy Ready Home Solar Thermal Checklist } \\
\text { and Specifications }\end{array}$ \\
\hline
\end{tabular}




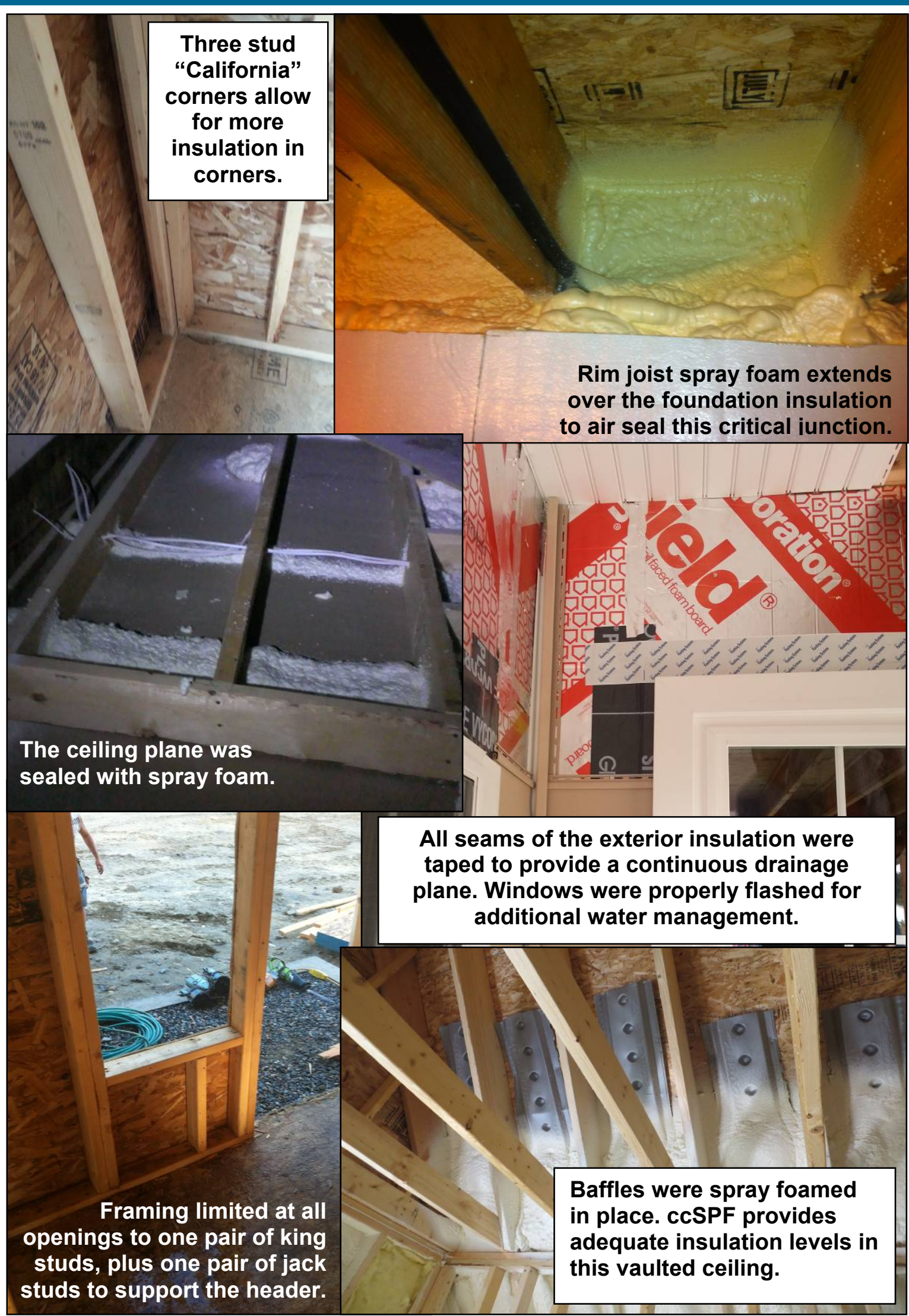

Figure 16. Several critical building envelope details 
In addition to specifications and inspection, several performance tests are required to verify compliance with the Zero Energy Ready Home requirements. These tests cover building infiltration, duct leakage, local and whole-house ventilation, hot water distribution, and supply air distribution.

\subsection{Building Infiltration}

A blower door test was performed to measure airflow and leakage characteristics that influence infiltration. This test is performed at a pressure differential of \pm 50 Pascal for uniformity between testers, but it does not provide specific information on how much outside air enters a building under normal operating conditions throughout the year. As shown in Table 8, these test data can be looked at in multiple ways to provide a variety of comparison to other similar dwellings. Regardless of the specific metric, the general takeaway is that this home is well air sealed and will minimize drafts felt by occupants. In addition to mechanical system design and distribution, this is one of the key factors in enabling a home to be comfortable.

Table 8. Blower Door Test Results

\begin{tabular}{|c|c|}
\hline $\mathrm{CFM}_{50}$ & 1,241 \\
\hline $\mathrm{CFM}_{50} / 100 \mathrm{ft}^{2}$ of Enclosure Area & 16.9 \\
\hline $\mathrm{CFM}_{50} / \mathrm{ft}^{2}$ of Floor Area & 0.28 \\
\hline $\mathbf{A C H}_{50}$ & 2.03 \\
\hline $\mathrm{ACH}_{50} / 100 \mathrm{ft}^{2}$ of Enclosure Area & 0.028 \\
\hline $\mathrm{ACH}_{50} / 100 \mathrm{ft}^{2}$ of Floor Area & 0.046 \\
\hline $\mathrm{ACH}_{\text {nat }}$ & 0.12 \\
\hline Effective Leakage Area (in. ${ }^{2}$ ) & 68.1 \\
\hline Effective Leakage Area $/ 100 \mathrm{ft}^{2}$ of Enclosure Area & 0.93 \\
\hline Effective Leakage Area $/ 100 \mathrm{ft}^{2}$ of Floor Area & 1.53 \\
\hline Specific Leakage Area & 0.00011 \\
\hline
\end{tabular}

At these levels of airtightness, combustion safety and strategic ventilation issues need to be addressed. Therefore, the furnace and water heater for this home were specified as sealed combustion units that draw their combustion air for the gas burners directly from outdoors. The gas range still uses interior combustion air, but it is not used as frequently as the other mechanical equipment. It is equipped with a kitchen hood ducted to the outside to exhaust combustion and cooling contaminants to the exterior.

\subsection{Duct Leakage}

A duct blaster test was performed to document the airtightness of the forced-air duct system. Two tests are performed on the duct system to quantify total duct leakage, which can impact comfort in individual rooms, and duct leakage to outside, which is an energy penalty and a potential source of contaminants into the home (return side duct leakage). This test is performed at a pressure differential of \pm 25 Pascal for uniformity between testers, but it does not provide specific information on how much duct leakage will occur under normal operating conditions. 
Table 9. Duct Blaster Test Results

\begin{tabular}{|c|c|}
\hline Total Leakage - CFM 25 & 299 \\
\hline $\mathrm{CFM}_{25} / \mathrm{CFM}_{\text {fan }}$ & 0.367 \\
\hline $\mathrm{CFM}_{25} / 100 \mathrm{ft}^{2}$ of floor area & 6.7 \\
\hline Leakage to Outside - $\mathrm{CFM}_{25}$ & 11 \\
\hline $\mathrm{CFM}_{25} / \mathrm{CFM}_{\mathrm{fan}}$ & 0.013 \\
\hline $\mathrm{CFM}_{25} / 100 \mathrm{ft}^{2}$ of floor area & 0.25 \\
\hline
\end{tabular}

Air sealing around the air handler, where operating pressures are the highest during normal operating conditions, is the most critical detail. In many instances, additional air sealing of the air handler cabinet is necessary. Appropriate UL-181A/B listed tape (CARB's preference is for an oriented polypropylene tape or foil-backed butyl tape) should be used on connections that may need future servicing, while permanent connections should be sealed with the appropriate UL181 A-M/B-M listed mastic.

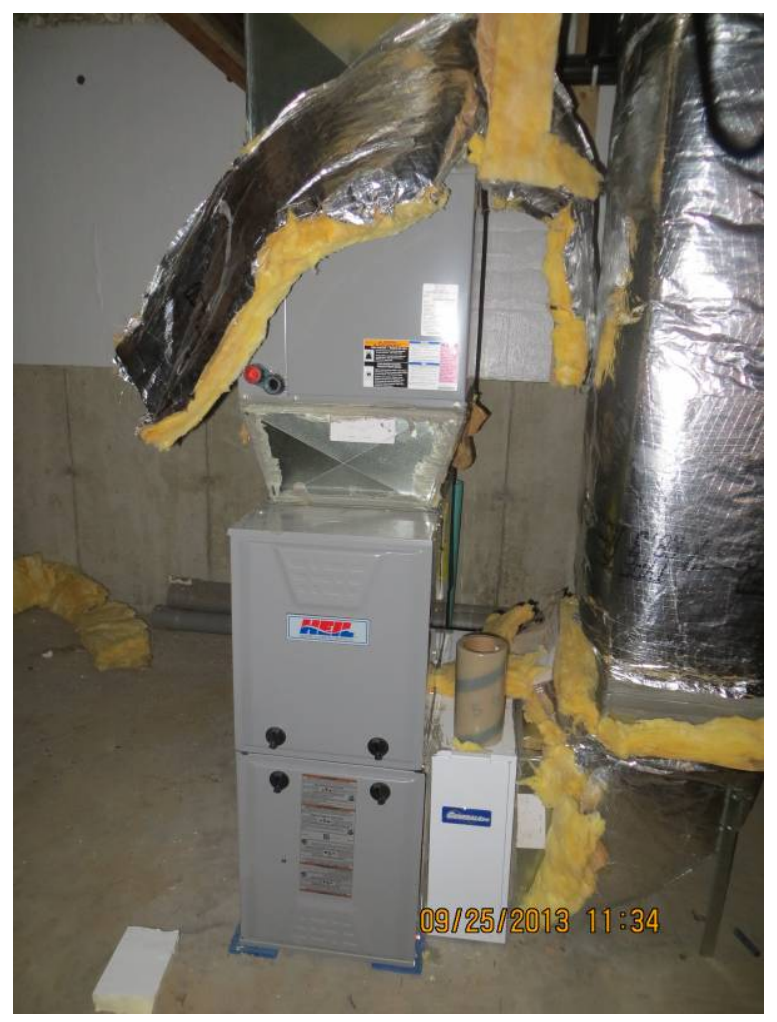

Figure 17. Air sealing around the air handler compartment

\subsection{Ventilation}

In this home, the local and whole-house ventilation is performed by the same exhaust fans. ENERGY STAR-certified exhaust fans with built-in continuous and delay off controls were installed in all bathrooms and the garage. In addition to being able to set a continuous low exhaust flow operation; these units have built-in motion detectors for override control to high speed when the space is occupied. The minimum flow rate for compliance with the ASHRAE 62.2-2010 continuous whole-house ventilation standard was $82 \mathrm{cfm}$. The bathrooms and garage delay off controls were set to 20 minutes and 1 hour, respectively. 
Table 10. Exhaust Ventilation Test Results

\begin{tabular}{c|c|c|c}
\hline Fan Location & $\begin{array}{c}\text { Rated Speed } \\
(\mathbf{c f m})\end{array}$ & $\begin{array}{c}\text { High Speed } \\
(\mathbf{c f m})\end{array}$ & $\begin{array}{c}\text { Continuous Speed } \\
\text { (cfm) }\end{array}$ \\
\hline Master Bathroom & 80 & 89 & 53 \\
\hline Second-Floor Bathroom & 80 & 74 & 37 \\
\hline Powder Room & 80 & 78 & - \\
Garage & 80 & 84 & - \\
\hline
\end{tabular}

\subsection{Hot Water Distribution}

To address water conservation, the DOE Zero Energy Ready Home certification program has pulled out one key requirement from the EPA WaterSense program. The requirement limits waste to 0.5 gal when hot water is called for at the furthest point from the water heater. This is to minimize the amount of water that occupants run down the drain while waiting for desired hot water. In terms of verification, the volume limit is actually 0.6 gal to account for additional water that might be removed from the system before hot water can be delivered. This design requirement was discussed with the builder, but was overlooked when the plumber installed the water distribution system. Figure 18 shows the estimated volume of hot water stored in the distribution cross-linked polyethylene piping (anything within the green shaded area should result in an acceptable test result). The main culprit for the high storage volumes is the use of a central trunk that runs from the basement up to the second floor for all branch takeoffs.

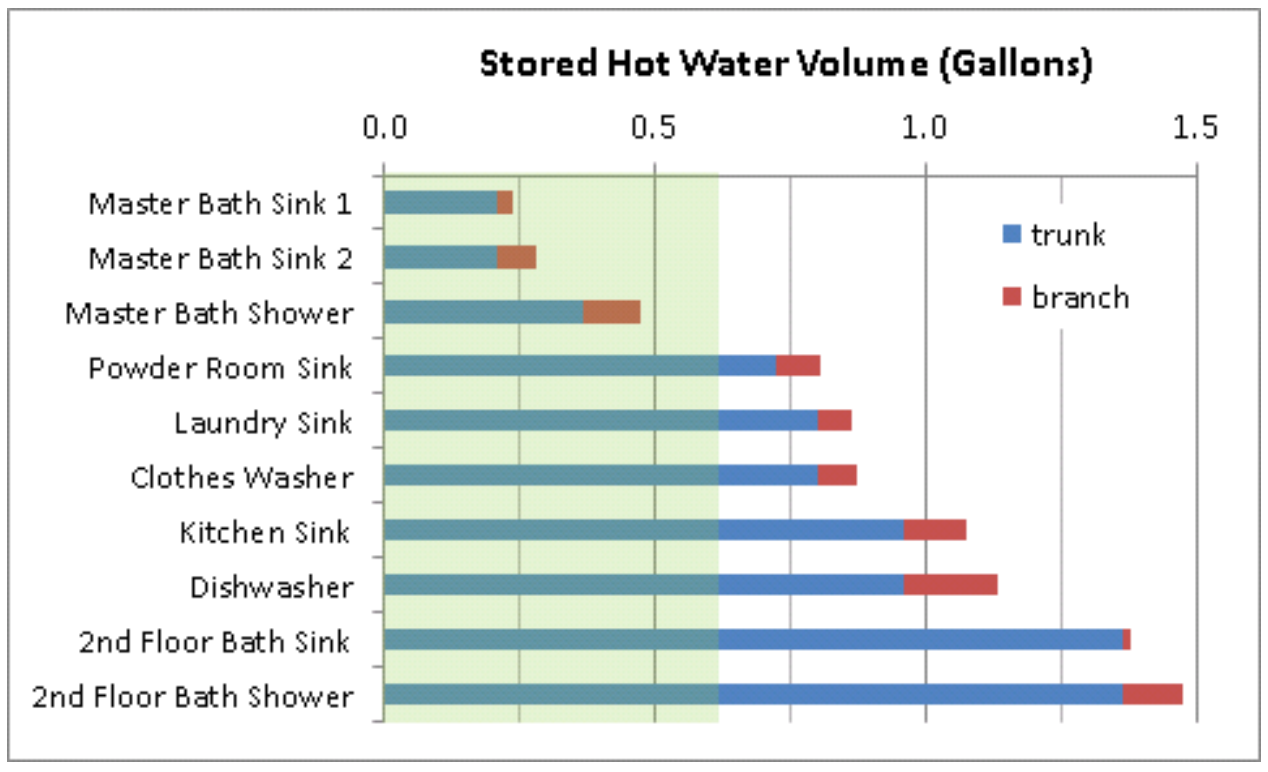

Figure 18. Estimated DHW volume stored in distribution piping

A solution to abate the excessive hot water storage volume was the use of an on-demand recirculation pump. For the Singer Village demonstration home, a recirculation pump was installed at the furthest bathroom (Figure 19) and on-demand control switches were installed in the laundry, kitchen, and second-floor bath to allow the main trunk line to be primed prior to a call for hot water. The recirculation pump could be retrofitted in as it uses the cold water line as the recirculation line back to the water heater. 


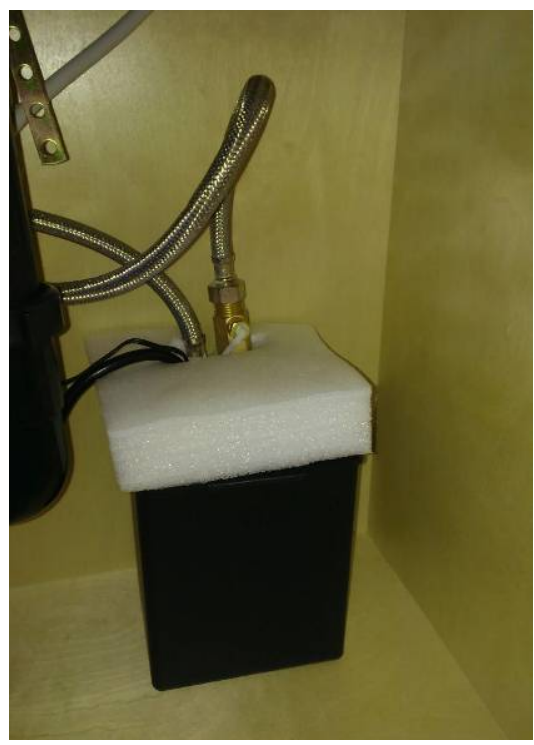

Figure 19. On-demand recirculation pump installed at furthest fixture

Additional testing of the hot water delivery system was performed. Prior to each test, the hot water piping was "cold water flushed" by shutting the water heater off and running water at the test fixture until a steady state mains temperature was achieved. The first test was for the sink in the furthest bathroom from the tankless water heater. As can be seen in Figure 21 , a $10^{\circ} \mathrm{F}$ temperature rise was not achieved until 58 seconds and a steady-state temperature of $116^{\circ} \mathrm{F}$ was not reached for nearly 2 minutes. Based on a $\sim 1.5$ gpm faucet aerator, the volume of stored water in the hot water distribution system was 1.45 gal, which is fairly close to the $1.38 \mathrm{gal}$ measurement estimate provided earlier in Figure 18. After the steady-state temperature was reached for the hot water, the faucet was shut off for 1 minute. After the minute, the hot water was turned back on to determine if there would be any "cold water sandwich" issues with this tankless hot water system. A cold water sandwich is when a small quantity of cold water passes through the water heater heat exchanger without warming up, as a tankless water heater takes a few seconds to heat up. The standing warm water in the pipes will be delivered, then a "slug" of cold water may briefly follow, and then followed up with the heated water from the water heater. Monitoring showed that for both calls of hot water after a one minute and five minute off period, the initial water out of the faucet had cooled off a couple degrees, but there was no significant sign of a cold water sandwich. There was a further slight dip in temperature by a degree or two just before steady-state temperature was reached again, but nothing that would be classified as a cold water sandwich.

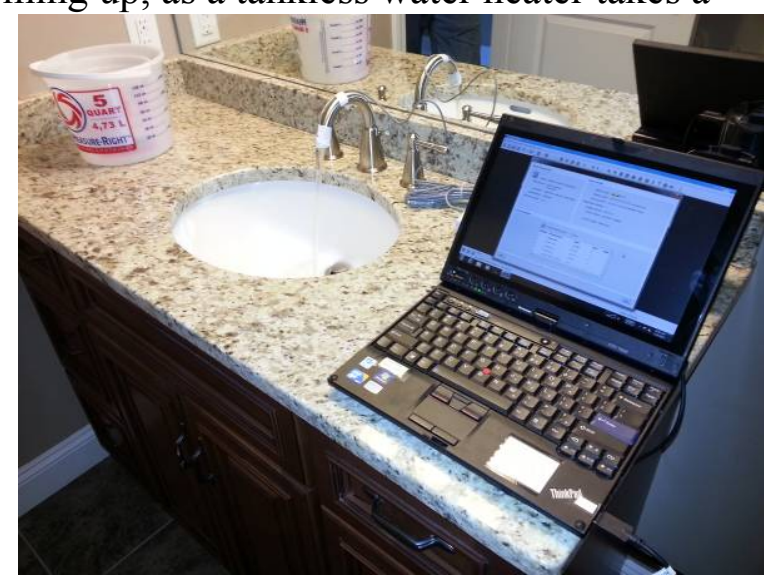

Figure 20. DHW monitoring setup

After another cold water flush of the hot water lines, the on-demand recirculation pump was energized. It operated for $\sim 55$ seconds before shutting off, which, as expected, closely matches the time of the $10^{\circ} \mathrm{F}$ temperature rise testing. 


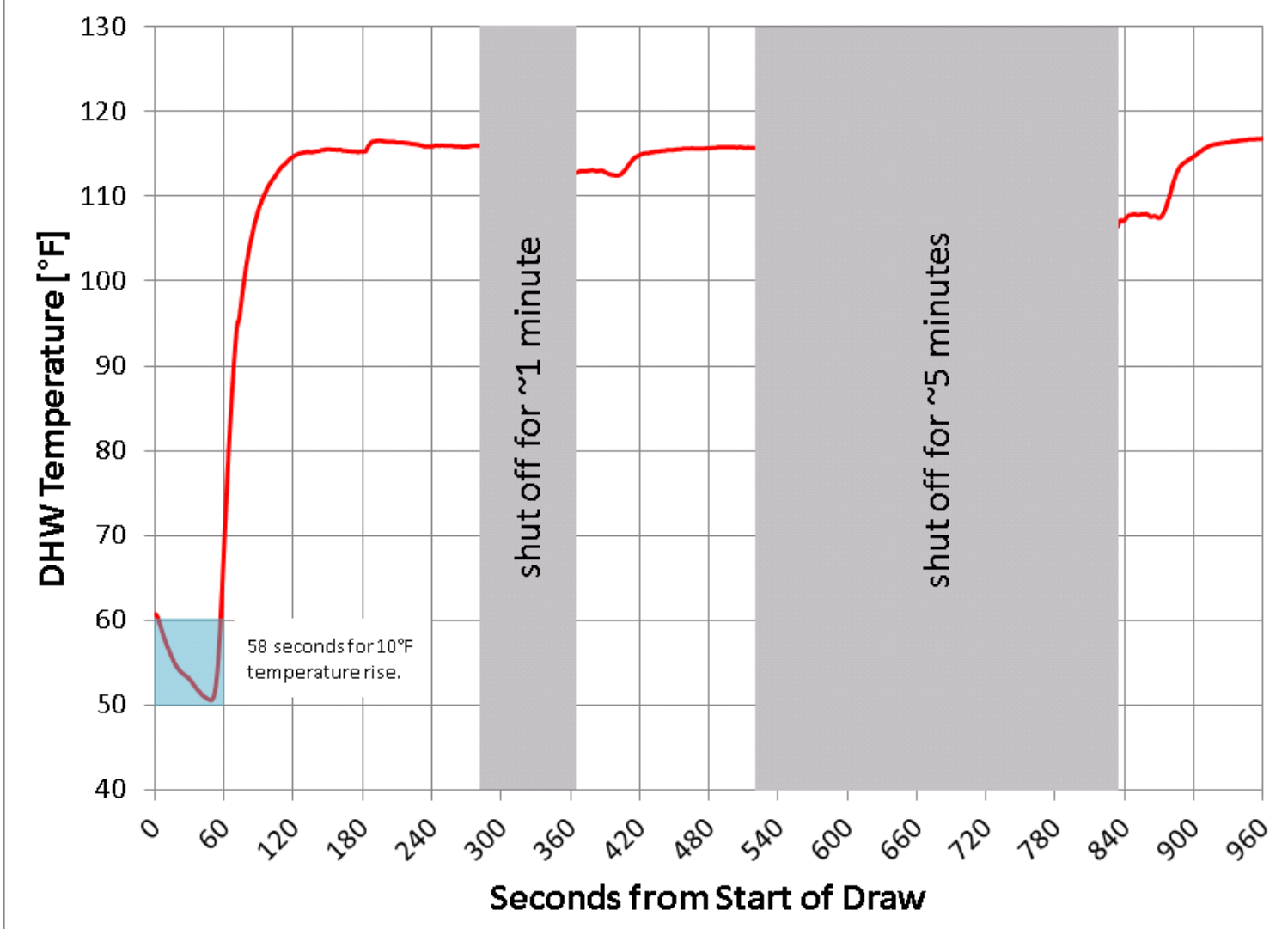

Figure 21. DHW testing of the second-floor bathroom sink

Testing of the master bathroom sink (nearest to the water heater) was also performed. As seen in Figure 22, this fixture meets the Zero Energy Ready Home requirements of greater than a $10^{\circ} \mathrm{F}$ temperature rise before 0.6 gal of water are drawn from the hot water distribution system. Still a steady-state temperature of $120^{\circ} \mathrm{F}$ was not meet for roughly 1 minute. It should also be noted that there is a $4^{\circ} \mathrm{F}$ difference in steady-state temperature between the nearest and furthest fixtures.

One key design aspect that must be considered in DOE Zero Energy Ready Homes is the lag time of tankless water heaters. While manufacturers are continually improving this, there is still a period of time in which the burners need to ignite and the heat exchanger needs to warm up. In the case of the master bathroom sink, the distribution pipe measurement estimates and field measurement of water flow rate, suggest that the system is holding just under 0.25 gal of hot water. Due to the lag in the tankless water heater, nearly double that amount of water needed to be flushed before the $10^{\circ} \mathrm{F}$ temperature rise was observed. Designers need to be aware that the selection of the water heater will also have an impact on the available distribution volume to comply with the DOE Zero Energy Ready Home water efficiency requirement. If a tankless water heater is utilized for a DOE Zero Energy Ready Home, it is recommended that electrical and control pre-wiring for a potential recirculation pump and on-demand switches be included in the design. This is minimal cost and will save significant time and money if there is a failure in the water efficiency requirement at final testing of the home. 


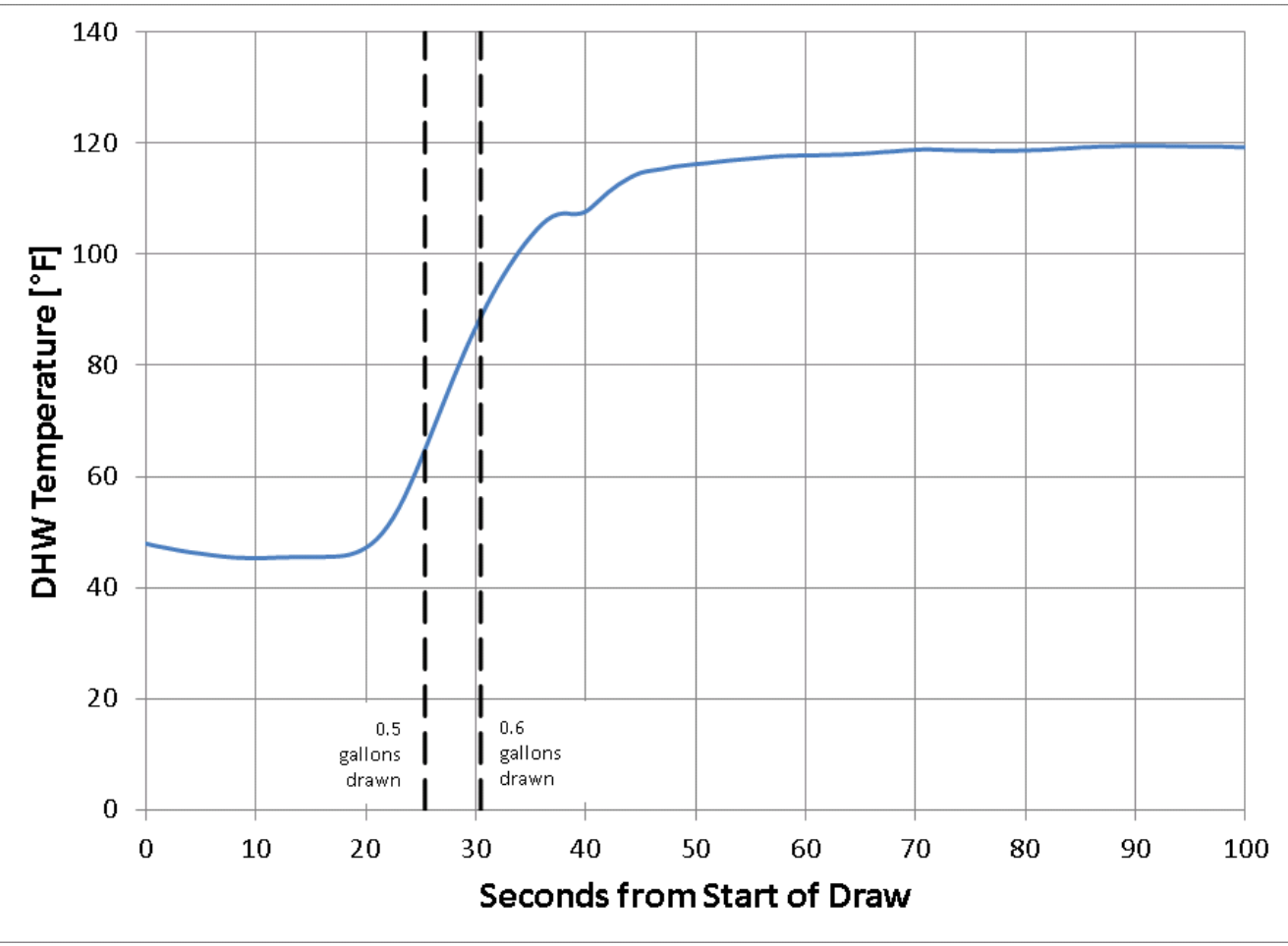

Figure 22. DHW testing of master bathroom sink

\subsection{Supply Distribution}

To ensure that each room is receiving the proper amount of space conditioning, system balancing of the supply registers was performed. Each supply branch had a manual balancing damper installed near the main trunk takeoff to allow for access in the unfinished basement. To be deemed compliant, measured supply airflows must be within the greater of $\pm 20 \%$ or $25 \mathrm{cfm}$ of design airflow. In the initial testing, after slight adjustments to balancing dampers to reduce the amount of airflow going to the second floor supplies, all supply registers were within $25 \mathrm{cfm}$ of the design (heating, high speed) flow rate. Still there was a desire to balance the system further to ensure that critical rooms, like the main living space (the open concept living room, dining room, and kitchen) and master bathroom, were adequately supplied. To increase airflow to the main living space, the first $10 \mathrm{ft}$ of the supply branches were increased to 5 in. ductwork and then transitioned back to 4 in. ductwork out to the supply boot and register. In addition, several restrictions in the flex ductwork were

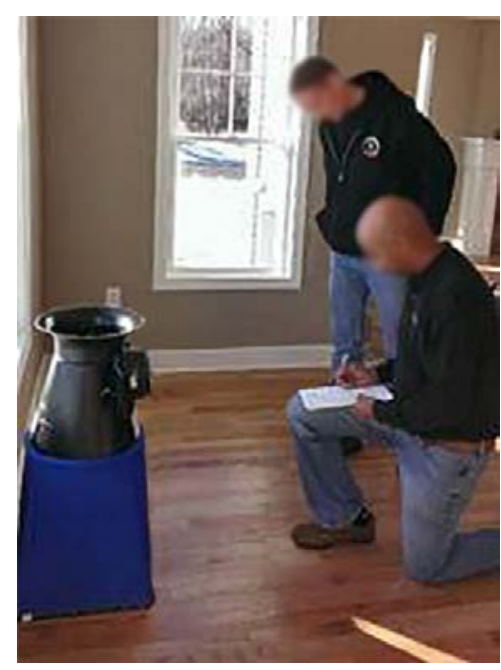

Figure 23. Measuring airflows with a low flow balometer fixed. As can be seen in Table 11 and Figure 24, this resulted in a better balancing and more total airflow (due to lower external static pressure). The supply branch in the dining room was still restricted due to the running on the ductwork in the outer floor joist where it was partially restricted by spray foam that was installed for insulating and air sealing the rim/band joist. To avoid this issue in the remaining homes to be built in this development, the HVAC contractor is revising the duct layout for this one supply. 
Table 11. HVAC Balancing Results

\begin{tabular}{|c|c|c|c|c|c|}
\hline \multirow{2}{*}{ Location } & $\begin{array}{c}\text { Design } \\
\text { Airflow }\end{array}$ & \multicolumn{2}{|c|}{$\begin{array}{c}\text { First Pass } \\
\text { Balancing }\end{array}$} & \multicolumn{2}{c}{$\begin{array}{c}\text { Second Pass } \\
\text { Balancing }\end{array}$} \\
\cline { 2 - 6 } & cfm & cfm & $\pm \mathbf{2 0 \%}$ & cfm & $\pm \mathbf{2 0 \%}$ \\
\hline Basement 1 & 20 & 22 & $\checkmark$ & 22 & $\checkmark$ \\
\hline Basement 2 & 20 & 19 & $\checkmark$ & 19 & $\checkmark$ \\
\hline Living Room 1 & 47 & 27 & low & 36 & $\checkmark$ \\
\hline Living Room 2 & 47 & 34 & low & 46 & $\checkmark$ \\
\hline Dining Room & 47 & 25 & low & 32 & low \\
\hline Foyer & 53 & 49 & $\checkmark$ & 51 & $\checkmark$ \\
\hline Laundry & 20 & 28 & high & 24 & $\checkmark$ \\
\hline Bath 2 & 7 & 18 & high & 15 & high \\
\hline Bedroom 2 & 46 & 40 & $\checkmark$ & 41 & $\checkmark$ \\
\hline Master Bath & 35 & 20 & low & 28 & $\checkmark$ \\
Master Bedroom 1 & 33 & 25 & $\checkmark$ & 35 & $\checkmark$ \\
Master Bedroom 2 & 33 & 28 & $\checkmark$ & 36 & $\checkmark$ \\
\hline Upper Hall & 67 & 76 & $\checkmark$ & 64 & $\checkmark$ \\
\hline Bedroom 3 & 57 & 68 & $\checkmark$ & 61 & $\checkmark$ \\
\hline Bath 3 & 16 & 26 & high & 22 & high \\
\hline Bedroom 4 & 52 & 62 & $\checkmark$ & 58 & $\checkmark$ \\
\hline Total & 600 & 567 & & 590 & \\
\hline
\end{tabular}

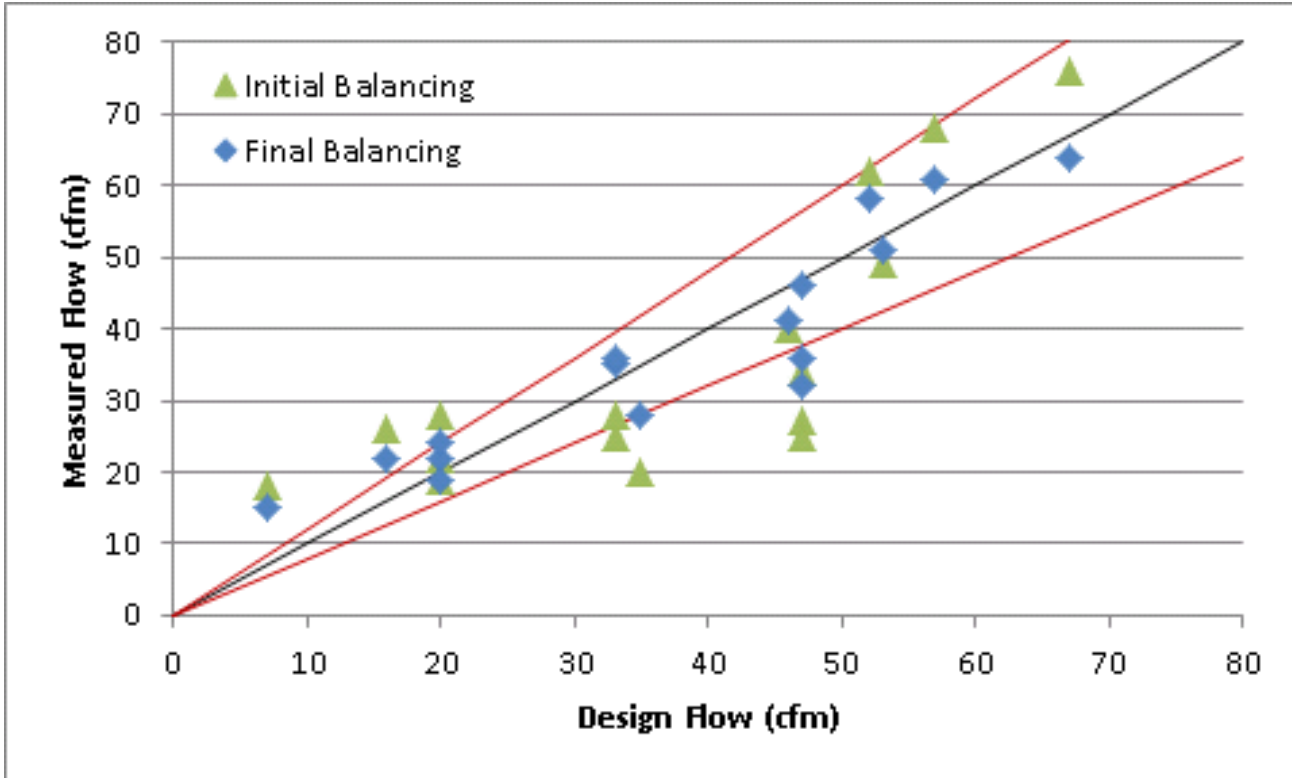

Figure 24. Comparison of design versus measured airflow before and after balancing (redline depicts $\mathbf{2 0} \%$ from the design flow) 


\section{Cost Benefit}

An evaluation of cost benefit with respect to homeowners and builders was performed. The value of the house can be estimated by perception of value, energy savings amortized over a period of time, or relative to the increase in purchasing power. The cost metrics used relative to homeowners were AERC and annual utility costs. AERC is calculated by annualizing the energy-related cash flows over the analysis period (30 years). This cash flow includes mortgage payments, replacement costs, utility bill payments, mortgage tax deductions, and residual values at the end of the analysis period. For builders, the cost metric is ROI.

\subsection{Operational Costs}

Operational costs of a building are a concern for homeowners. Figure 25 shows the impact of each measure on the incremental savings in annualized utility bills. The estimated annual utility savings over a code-compliant home are $\$ 891 /$ year or $\$ 74 /$ month, which is substantial considering that the U.S. average utility (natural gas and electricity) cost for the winter season is about $\$ 132 /$ month (EIA 2013).

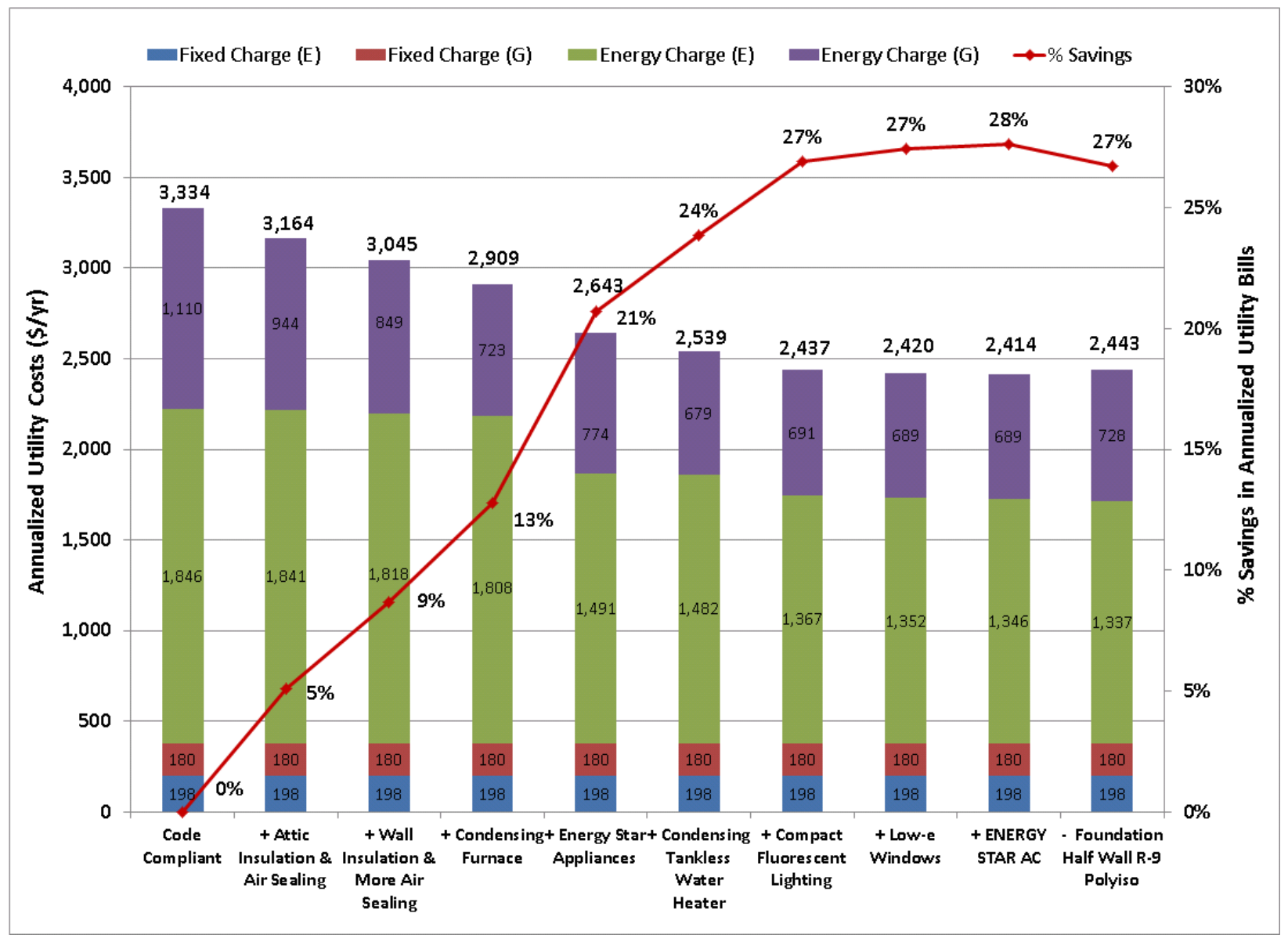

Figure 25. Cumulative contribution to utility bills by measure and end use 
In Figure 26, the modeled annual energy cost savings of this DOE Zero Energy Ready Home was compared to the three market alternatives: a 2009 IECC-compliant home, a 2003 IECCcompliant home, and an existing home from the mid-90s. For this analysis, a fuel escalation rate of $0.2 \%$ and $0.8 \%$ was applied to the electricity and natural gas fuel cost, respectively. The fuel escalation was obtained from the estimated percentage change in electricity and natural gas prices compounded annually from 2010 to 2015 for Connecticut (Rushing and Lippiatt 2010).

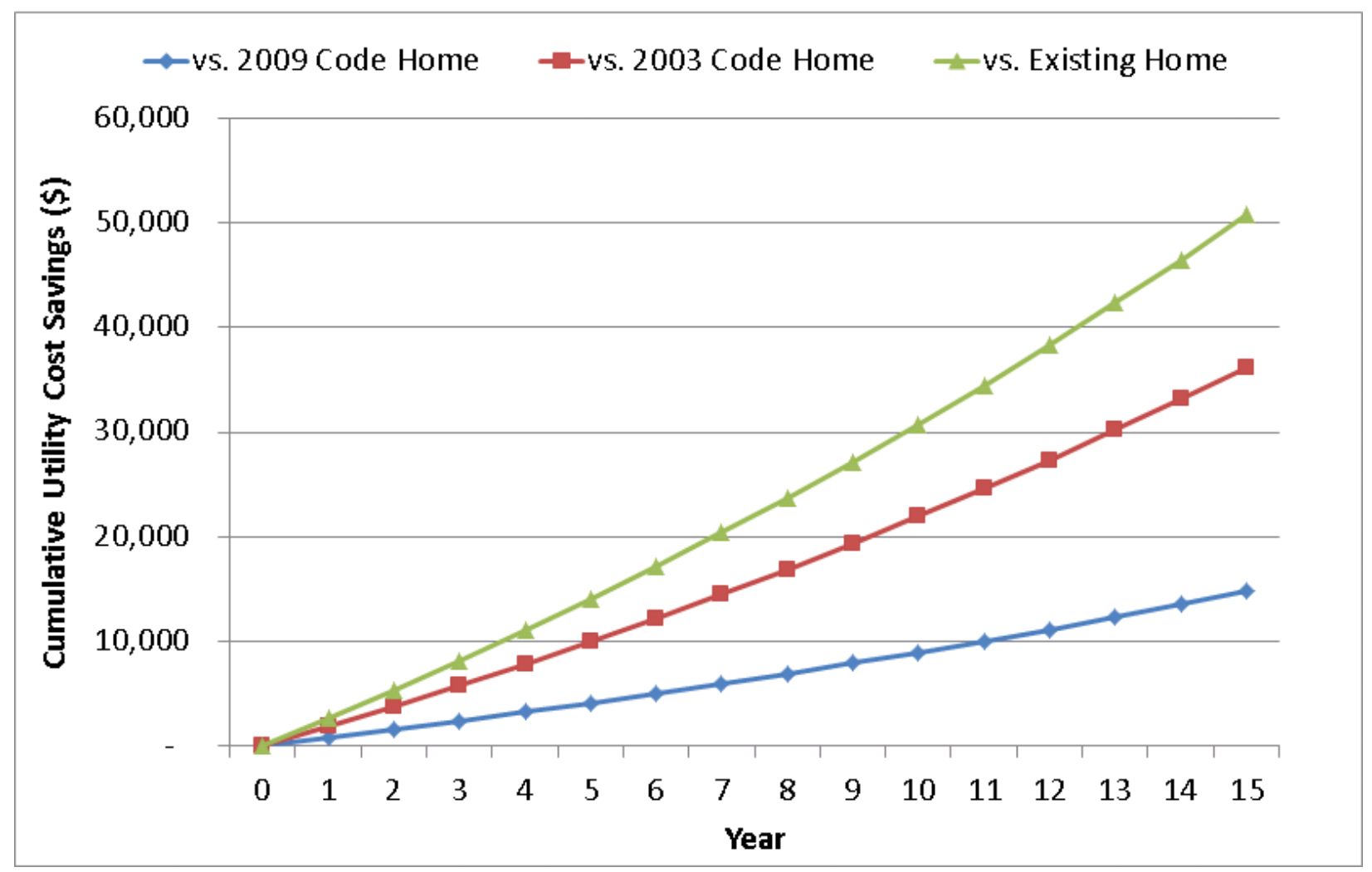

Figure 26. Utility cost savings of the Singer Village demonstration home over alternative market options

\subsection{Cost of Homeownership}

The monthly cost of homeownership of this home was compared to similar homes with lower performance requirements to demonstrate to a potential homebuyer the cost benefit of owning a DOE Zero Energy Ready Home. Brookside Development provided the estimates for insurance, property tax, and first-year maintenance (builder's estimate for items that would typically need to be fixed or replaced in an older existing home in the first year). Even though the selected design is selling at a higher initial purchase price compared to the alternative market options, with lower utility and maintenance costs, the cost of owning this high performance home is actually lower over time. Again, in addition to the long-term monetary benefits, there are significant benefits in comfort, indoor air quality, and durability that are unaccounted. 
Table 12. Homeownership Cost Comparison of Brookside Development's Zero Energy Ready Home Versus Similar Lower Performance Homes

\begin{tabular}{|c|c|c|c|c|}
\hline & $\begin{array}{l}\text { Zero } \\
\text { Energy } \\
\text { Ready } \\
\text { Home } \\
\end{array}$ & $\begin{array}{l}2009 \text { Code } \\
\text { Home }\end{array}$ & $\begin{array}{l}2003 \text { Code } \\
\text { Home }\end{array}$ & $\begin{array}{l}\text { Existing } \\
\text { Home }\end{array}$ \\
\hline Purchase Price & $\$ 474,900$ & $\$ 439,000$ & $\$ 379,000$ & $\$ 329,000$ \\
\hline Down Payment (20\%) & $\$ 94,980$ & $\$ 87,800$ & $\$ 75,800$ & $\$ 65,800$ \\
\hline Loan Amount & $\$ 379,920$ & $\$ 351,200$ & $\$ 303,200$ & $\$ 263,200$ \\
\hline Length of Mortgage (years) & 30 & 30 & 30 & 30 \\
\hline Yearly Mortgage Interest Rate & $4.5 \%$ & $4.5 \%$ & $4.5 \%$ & $4.5 \%$ \\
\hline Mortgage (per month) & $\$ 1,925$ & $\$ 1,779$ & $\$ 1,536$ & $\$ 1,334$ \\
\hline Insurance (per month) & $\$ 100$ & $\$ 100$ & $\$ 100$ & $\$ 100$ \\
\hline Property Tax (per month) & $\$ 580$ & $\$ 580$ & $\$ 550$ & $\$ 525$ \\
\hline $\begin{array}{l}\text { Estimated First-Year } \\
\text { Maintenance/Replacement Cost } \\
\text { (per month) }\end{array}$ & $\$ 10$ & $\$ 50$ & $\$ 206$ & $\$ 365$ \\
\hline Heating (per month) & $\$ 48$ & $\$ 99$ & $\$ 199$ & $\$ 257$ \\
\hline Water Heating (per month) & $\$ 10$ & $\$ 27$ & $\$ 29$ & $\$ 32$ \\
\hline Cooling (per month) & $\$ 5$ & $\$ 8$ & $\$ 20$ & $\$ 40$ \\
\hline $\begin{array}{l}\text { Lighting, Appliances, and } \\
\text { Miscellaneous (per month) }\end{array}$ & $\$ 109$ & $\$ 115$ & $\$ 115$ & $\$ 115$ \\
\hline $\begin{array}{c}\text { Utility Service Charge (per } \\
\text { month) }\end{array}$ & $\$ 32$ & $\$ 32$ & $\$ 32$ & $\$ 32$ \\
\hline $\begin{array}{c}\text { Estimated Tax Benefit (per } \\
\text { month, based on } 25 \% \text { bracket) }\end{array}$ & $(\$ 511)$ & $(\$ 472)$ & $(\$ 408)$ & $(\$ 354)$ \\
\hline Estimated Total Monthly Cost & $\$ 2,308$ & $\$ 2,318$ & $\$ 2,379$ & $\$ 2,446$ \\
\hline
\end{tabular}

\subsection{Market Value}

The cost benefit for the builder for incorporating energy efficiency is not in the operational cost savings, but rather in the added value to the home's sale price. With regards to valuing energy efficiency measures implemented in a home, there is yet to be a universally accepted tool that provides valuations based on the level of efficiency.

One measure that is starting to see support by the Appraisal Institute for added home value is PV systems. While this is related to renewable energy generation, rather than energy efficiency, it is a starting point to valuing "green" home features. Using the PV Value spreadsheet tool developed by Sandia National Laboratories, a 5-kW PV system (with local rebates and federal tax credits, the costs of this system can be as low as $\$ 9,000-\$ 13,000)$ adds $\$ 26,000-\$ 31,000$ to the sale value of a home.

In an attempt to ensure additional value is given to energy efficiency measures in buildings, the Appraisal Institute issued its Residential Green and Energy Efficient Addendum ${ }^{5}$ to Fannie Mae Form 1004. This addendum provides a means for appraisers to add monetary value when

\footnotetext{
${ }^{5}$ http://www.appraisalinstitute.org/assets/1/7/AI_820_04-Residential_Green_and_Energy_Effecient_Addendum.pdf
} 
assessing green homes, but there is little information to guide appraisers with these valuations (Appraisal Institute 2013).

For this first Singer Village demonstration home, Brookside Development has provide CARB with incremental costs for several key efficiency measures and the anticipated added home value for each of these measures based upon past home sales. This information, along with an estimate of ROI, as defined in Equation 1, is provided in Table 13.

$$
\mathrm{ROI}=(\text { Added Value }- \text { Incremental Cost }) / \text { Incremental Cost }
$$

If an investment does not have a positive ROI, or if there are other opportunities with a higher ROI, the investment should be not be undertaken. For this demonstration home, all efficiency measures were found to be cost beneficial to the builder except for the inclusion of the heat pump.

Table 13. Estimated Builder Return on Investment for Various Energy Efficiency Measures

\begin{tabular}{|c|c|c|c|c|c|}
\hline Component & 2009 IECC & $\begin{array}{c}\text { As-Built } \\
\text { Specification }\end{array}$ & $\begin{array}{l}\text { Incremental } \\
\text { First Cost }\end{array}$ & $\begin{array}{c}\text { Estimated } \\
\text { Added } \\
\text { Value }\end{array}$ & ROI \\
\hline $\begin{array}{c}\text { Foundation } \\
\text { Assembly }\end{array}$ & $\begin{array}{l}\text { Whole wall, R-10 } \\
\text { insulation }\end{array}$ & $\begin{array}{l}\text { Half wall, R-13 } \\
\text { polyisocyanurate, } \\
\text { critical air seal of } \\
\text { rim/band joists }\end{array}$ & $-\$ 250$ & $\$ 3,500$ & High ROI \\
\hline $\begin{array}{c}\text { Above- } \\
\text { Grade Wall } \\
\text { Assembly }\end{array}$ & $\begin{array}{c}\text { R-13 cavity } \\
\text { insulation, } 2 \times 4,16 \\
\text { in. o.c., } \mathrm{R}-5 \\
\text { exterior insulation }\end{array}$ & $\begin{array}{l}\text { R-18 2-in. ccSPF and } \\
2 \text { in. compressed } \\
\text { FGB, } 2 \times 4,16 \text { in. } \\
\text { o.c. OSB, R-6 } \\
\text { polyisocyanurate }\end{array}$ & $\$ 3,400$ & $\$ 6,000$ & $76 \%$ \\
\hline $\begin{array}{l}\text { Ceiling } \\
\text { Assembly }\end{array}$ & $\mathrm{R}-38$ insulation & $\begin{array}{l}\text { R- } 60 \text { blown cellulose, } \\
\text { critical seal of ceiling } \\
\text { plane }\end{array}$ & $\$ 2,400$ & $\$ 5,000$ & $108 \%$ \\
\hline $\begin{array}{l}\text { Heating } \\
\text { System }\end{array}$ & $\begin{array}{l}78 \text { AFUE natural } \\
\text { gas furnace }\end{array}$ & $\begin{array}{l}96 \text { AFUE natural gas } \\
\text { condensing, two- } \\
\text { stage furnace }\end{array}$ & $\$ 1,000$ & $\$ 2,000$ & $100 \%$ \\
\hline $\begin{array}{l}\text { Cooling } \\
\text { System }\end{array}$ & $\begin{array}{l}\text { SEER } 13 \text { air } \\
\text { conditioner }\end{array}$ & $\begin{array}{c}\text { SEER 14/8.0 HSPF } \\
\text { ASHP }\end{array}$ & $\$ 1,400$ & $\$ 0$ & No ROI \\
\hline $\begin{array}{l}\text { Water } \\
\text { Heating }\end{array}$ & $\begin{array}{c}0.59 \text { EF natural gas } \\
50 \text {-gal storage } \\
\text { water heater }\end{array}$ & $\begin{array}{c}\text { 0.94 EF natural gas } \\
\text { condensing tankless } \\
\text { water heater }\end{array}$ & $\$ 1,000$ & $\$ 2,000$ & $100 \%$ \\
\hline
\end{tabular}

Furthermore, there could be other ancillary values of high performance home construction for builders. These additional values could include market recognition, reduced time of homes on the market, and reduced warranty costs.

\subsection{Environmental Benefits}

In addition to the energy and cost savings associated with this high performance home, there are ancillary benefits, such as improved comfort, indoor air quality, and reduced greenhouse gas emissions. Table 14 provides the carbon dioxide, sulfur dioxide, and nitrogen oxide savings of this demonstration home over a similar 2009 IECC-compliant home. 
Table 14. Reduction in Greenhouse Gas Emissions

\begin{tabular}{c|c|c}
\hline \multirow{2}{*}{ Greenhouse Gas } & \multicolumn{2}{|c}{ Annual Emission Savings } \\
\cline { 2 - 3 } & w/o PV & w/ 5 kW PV \\
\hline Carbon Dioxide & $5.7 \mathrm{tons}$ & $7.5 \mathrm{tons}$ \\
Sulfur Dioxide & $2.4 \mathrm{lb}$ & $4.7 \mathrm{lb}$ \\
Nitrogen Oxide & $12.1 \mathrm{lb}$ & $14.3 \mathrm{lb}$ \\
\hline
\end{tabular}

Over a 30-year period, the environmental benefit of reducing these emissions is estimated to be equivalent to avoiding the electricity usage of 22 households for 1 year, planting 1,641 fully mature trees, eliminating 502,531 miles driven by an average passenger car, or taking 38 passenger cars off the road for 1 year (Renewable Choice Energy 2013).

\subsection{Market Barriers}

In addition to the valuation issue of energy-efficient features with home appraisers that was discussed in Section 5.3, another major market barrier is that most prospective homeowners have never experienced a high performance home. They are simply unaware of how a properly built home should operate and feel, so they are not demanding it. In the case of Brookside Development, the builder uses a couple simple methods to provide a quick high performance home experience to potential home buyers. Salespeople will typically have less than 15 minutes to engage visitors, so optimizing the messaging is critical.

"We're promoting the energy efficiency of green because that puts green in your pocket." - Mark Nuzzolo, Brookside Development LLC (Source: The New York Times 2010)

When a prospective homeowner walks into this home, there are plaques of the building certifications (ENERGY STAR Qualified Homes, Indoor airPLUS, DOE Zero Energy Ready Home, etc.), the builder's past awards, and a first-year energy guarantee for the home. Simply stated, the builder will pay any utility costs above a specified amount for heating, hot water, and cooling. Through modeling and collecting utility bills from many of his previously built homes, this builder is able to comfortably provide a utility cost guarantee.

In each of the rooms, there are temperature sensors with digital readouts. After introductions and general information on the home, the salesperson suggests that prospective homeowners take a look at the temperature sensors throughout the home as they do their walk-

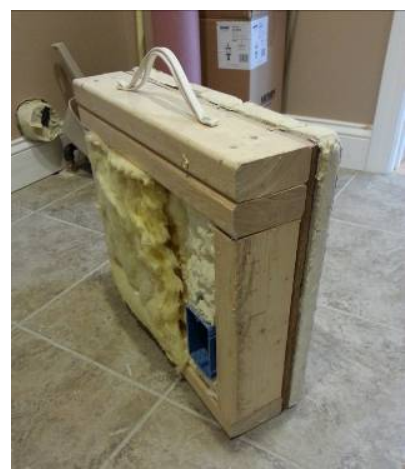

Figure 27. Small mockup of wall assembly through. Once completed, the salesperson points out the uniformity of temperature throughout the home and shows a small mockup of the wall assembly (Figure 27) to provide a quick visual overview of the efforts taken to construct the high performance home. Also, this home is solar ready, so the builder is set up to work with any homebuyer to install solar PV on the home to further reduce the operational costs of the home. 


\section{Conclusions}

This research home was used to identify and vet a viable DOE Zero Energy Ready Home solution package that can be readily implemented in the cold climate zone for new construction single-family production homes. The primary questions addressed by this research were:

- What solution package(s) can be readily implemented in a cold climate home to achieve DOE Zero Energy Ready Home certification?

The key features of any viable solution package are a building envelope with continuous thermal, air, and moisture barriers and a simplified HVAC system designed to provide comfort as efficiently as possible. The basic cold climate package for the Singer Village Homes was: (1) flash and batt cavity insulation with exterior rigid insulation; (2) critical air sealing of penetrations, the ceiling plane, and rim/band joist area; (3) properly designed HVAC with efficient heating equipment; and (4) field performance testing and HVAC commissioning to ensure the home performs as designed. Several variations of the CARB-recommended solution package were discussed in Section 3 and all would still comply with the DOE Energy Ready Home requirements.

For the building envelope, it was essential to air seal the transitions between the foundation, above-grade walls, and the roof. For the above-grade walls, $1 \mathrm{in}$. of polyisocyanurate rigid insulation was applied to the exterior of the sheathing and taped at the seams to provide the continuous barriers. To ensure optimal performance, a flash and batt cavity insulation strategy was utilized to further air seal the wall assembly and prevent potential condensation in the wall assembly from interior driven moisture. To continue these barriers in the foundation, ccSPF was used in the rim/band joist areas and overlapped the foundation interior wall insulation. Finally the ceiling plane was air sealed with spray polyurethane foam prior to blowing loose-fill insulation to the desired insulation depth.

The mechanical systems focused on a simplified system to provide heating and hot water as efficiently as possible. The only significant difference between the as-built home and CARB's solution package was the whole-house ventilation system. While a balanced ventilation system with energy/heat recovery is considered by most to be the best option, exhaust-only ventilation systems have been found to be effective and affordable in providing whole-house ventilation. For this builder to switch to an ERV in future homes, the $\$ 1,250$ incremental cost premium of an ERV over the exhaust-only system would need to be reduced by half or more. An additional benefit of exhaust-only systems is the very low maintenance requirements. Maintaining filters in furnaces is already sporadically done by homeowners, adding an additional unit that requires maintenance biannually was not desired by this builder.

- Is that solution package commercially viable? Where are opportunities to reduce costs in this solution package?

As discussed in Section 5, this solution package is viable for both potential homeowners and for builders. The monthly out-of-pocket cost for homeowners is estimated to be 
lower for this home versus similar alternatives available on the market. It should be difficult for a homeowner to turn down \$130-\$1,657 in additional money each year and the opportunity to actually be comfortable in the home. It falls to the salespeople to educate potential homeowners on the value of a high performance home.

From the builder perspective, the incremental cost to achieve this DOE Zero Energy Ready Home was 5.5\% more for the builder, while adding an estimated $8.2 \%$ of additional value to the home. In the remaining homes to be built in this subdivision, the builder's cost can be reduced an additional $0.6 \%$ by installing a standard air conditioner rather than the ASHP for the dual-fuel capability.

- What were the biggest challenges to complying with DOE Zero Energy Ready Home requirements? How were these challenges addressed by this builder?

Complying with the water efficiency requirement is difficult without incorporating an ondemand recirculation pump or revising floor plans to have all water areas centrally located to minimize the length of the hot water distribution system. In addition, when using a tankless water heater, the lag time of the heat exchanger getting to full temperature will make the water efficiency requirement substantially more challenging to achieve without a recirculation pump.

The end result of this demonstration home was a DOE Zero Energy Ready Home that achieved a HERS Index of 45 (HERS Index of 26 with a 5.4-kW PV system being offered to homeowners). This home was also awarded the 2013 Connecticut Zero Energy Challenge Award in the affordability category, as it had the lowest $\$ / \mathrm{ft}^{2}$ construction cost (just for structure from foundation up) of the 11 applicants. An Energize Connecticut video for this project can be viewed here: https://www.youtube.com/watch?v=3yS6XuRxtaM. 


\section{References}

Appraisal Institute (2013). Appraisal Institute Releases Enhanced Form to Help Real Estate Appraisers Analyze ‘Green' Features. Accessed October 24, 2013:

http://www.appraisalinstitute.org/newsadvocacy/news/2013/Appraisal-Institute-ReleasesEnhanced-Form-to-Help-Real-Estate-Appraisers-Analyze-Green-Features-03-07-13.aspx.

EIA (2013). U.S. Energy Information Administration Short-Term Energy Outlook, October 2013. Accessed October 23, 2013:

http://www.eia.gov/todayinenergy/detail.cfm?id=13311\#tabs_SpotPriceSlider-1.

Hendron, R.; Engebrecht, C. (2010). Building America House Simulation Protocols. Golden, CO: National Renewable Energy Laboratory. Accessed December 29, 2012:

http://www.nrel.gov/docs/fy11osti/49246.pdf.

Renewable Choice Energy (2013). Business Carbon Calculator. Accessed October 18, 2013: http://www.renewablechoice.com/business-carbon-calculator-report.html?type=report.

Rushing, A.S.; Lippiatt, B. C. (2010). Energy Price Indices and Discount Factors for Life-Cycle Cost Analysis - 2009, National Institutes of Standards and Technology, Washington, DC.

The New York Times (2010). Connecticut Home Builders Promote Energy Savings. Accessed March 5, 2014: http:/www.nytimes.com/2010/10/24/realestate/24wczo.html? r $=0$. 


\section{Appendix A: Impact of Mortgage Interest Rate on Cost Analysis}

The 2010 BA House Simulation Protocol sets mortgage interest rate at 7\%; however, current interest rates range between $3 \%-5 \%$. This raises a concern about the accuracy of the cost analysis in the model. To address this concern, the effect of different mortgage interest rates on AERC was analyzed. Results from BEopt indicated that the AERC decreased from $\$ 3,049$ to $\$ 3,023$ when mortgage interest rates increased from $3 \%$ to $7 \%$, but the percentage decrease is minimal $(0.9 \%)$. As expected, increasing mortgage interest rate increases loan interest rate as well as loan tax deduction. After annualizing the cash flows, AERC for a 7\% mortgage interest rate was found to be slightly lower than that of $3 \%$. Thus, it can be concluded that the impact of the mortgage interest rate used in the energy analysis does not drastically change the AERC. 


\section{Appendix B: Impact of Fuel Escalation Rate on Cost Analysis}

Four fuel escalation rates were analyzed to understand the effect on AERC. The 2010 BA House Simulation Protocol sets the fuel escalation rate at zero, but from 2010 to 2015 the estimated percentage change in electricity and natural gas prices compounded annually for census region 1 which includes Connecticut, is $0.2 \%$ and $0.8 \%$ respectively (Rushing and Lippiatt 2010). The results on the AERC at these particular rates are shown in the last row in Table 15 and it is $4.6 \%$ and $3.1 \%$ greater than that of the design without and with PV, respectively. Analysis of alternative fuel escalation rates (equal rates for electricity and natural gas) are also provided in Table 15.

Table 15. Effects of Real Fuel Escalation Rates on AERC

\begin{tabular}{|c|c|c|c|c|c|}
\hline \multirow{2}{*}{$\begin{array}{l}\text { Fuel Escalation Rates for } \\
\text { Both Electricity and } \\
\text { Natural Gas (\%/year) }\end{array}$} & \multicolumn{3}{|c|}{ AERC (\$/year) } & \multicolumn{2}{|c|}{$\begin{array}{c}\text { Percentage Higher } \\
\text { Than Design in Bold } \\
(\%)\end{array}$} \\
\hline & $\begin{array}{c}\text { BA } \\
\text { Benchmark }\end{array}$ & $\begin{array}{c}\text { Design w/o } \\
\text { PV }\end{array}$ & $\begin{array}{l}\text { Design } \\
\text { w/ PV }\end{array}$ & $\begin{array}{c}\text { Design w/o } \\
\text { PV }\end{array}$ & $\begin{array}{c}\text { Design w/ } \\
\text { PV }\end{array}$ \\
\hline 0.00 & 4,022 & 3,023 & 3,651 & - & \\
\hline 0.25 & 4,130 & 3,102 & 3,741 & 2.6 & 2.5 \\
\hline 0.50 & 4,242 & 3,183 & 3,746 & 5.3 & 2.6 \\
\hline 0.75 & 4,360 & 3,270 & 3,797 & 8.2 & 4.0 \\
\hline 1.00 & 4,483 & 3,360 & 3,850 & 11.1 & 5.5 \\
\hline 1.25 & 4,612 & 3,454 & 3,905 & 14.3 & 7.0 \\
\hline $0.2 / 0.8 *$ & 4,218 & 3,162 & 3,765 & 4.6 & 3.1 \\
\hline
\end{tabular}

*electricity/natural gas escalation rate 


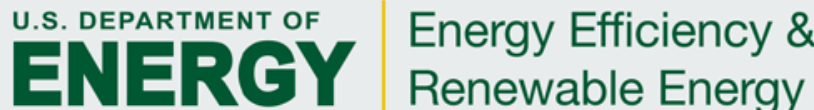

